\title{
TÜRK AİLE MAHKEMELERİ
}

\author{
Doç.Dr. Erdal TERCAN*
}

\section{A - GENEL OLARAK}

Aile mahkemeleri, 9.1.2003 tarihli ve 4787 sayılı "Aile Mahkemelerinin Kuruluş, Görev ve Yargılama Usullerine Dair Kanun"i ile kurulmuştur ${ }^{2}$. Kanunun amact, 1 inci maddesine göre, aile mahkemelerinin kuruluş, görev ve yargılama usullerini düzenlemektir.

Aile, toplumu oluşturan en temel, vazgeçilemez bir kurum, temel bir birim olarak, geçmişte olduğa gibi, günümüzde de, çok büyük bir öneme sahiptir. Devletin ve toplumun, sağlıklı bir şekilde işleyebilmesi ve varlığımı devam ettirebilmesi, toplumun en küçük birimi olan aileye bağlıdır. Ailenin, bu önemli fonksiyonların yerine getirebilmesi için, daha baştan sağlıklı bir şekilde kurulması ve varlığını devam ettirmesi zorunludur. O nedenle, aile hukukundan doyan ilişkiler, esas itibariyle özel hukuka girmesine, özel hukuk alanında Devletin müdahalesi oldukça az olmasına rağmen, Devletin, aile hukukuna müdahalesi, özel hukuka dahil olan diğer hukuk dallarına oranla, daha fazladır.

Ailenin, gelişmesi, sahip olduğu bu önemli fonksiyonlarını yerine getirebilmesi için, sosyal ve ekonomik yönlerden olduğu gibi, hukuki açıdan da korunması gereklidir. Nitekim, aile mahkemelerinin kurulmasına ilişkin Hükümet Gerekçesinde, bu hususa da değinilmekte ve şöyle denilmektedir: "Anayasanın "Ailenin Korunması" kenar başlıklı 41 inci maddesinde, ailenin Türk toplumunun temeli olduğu ve Devletin, ailenin huzur ve refahı ile özellikle ananın ve çocukların korunması için gerekli tedbirleri alacağı ve gereken teşkilâtı kuracağı belirtilmektedir. Toplumun temelini oluşturan

* Ankara Universitesi Hukuk Fakültesi Medeni Usul ve İcra - Iffâs Hukuku Anabilim Dalı Ögretim Uyesi.

' Bu Kanun için metin içerisinde AMK kısaltmast kullanılacaktır.

"RG 18 Ocak 2003, Sa 24997. 
ailenin korunması için gerekli önlemlerin alınması ihtiyacı her geçen gün artmaktadır. Hiç şiiphesiz, bir toplumda sosyal barış ve adaletin sağlanmasında, demokratik haklara saygılı, sağlıklı, topluma yararlı bireylerin yetiştirilmesinde ailenin önemi inkar edilemez bir gerçektir. Ailenin korunması görevi ise Devlete aittir. Günümüzde bir çok sahada olduğu gibi, sosyal yapıdaki baş döndürücü gelişmeler ve karmaşıklık. eşlerin ve çocukların da sorunlarının artmasına ve olumsuzluklar yaşamalarına neden olabilmektedir. Bu sorunların çözümünde yargı alanına giren konular bakımından da bir takım yenilikler getirilmesi zorunluluğu bulummaktadir.

Bir çok ülkenin iç hukuklarında aile mahkemelerine ilişkin düzenlemelerin yer aldığı, örneğin Kanada ve Almanya'da aile mahkemeleri bulunduğu bilinmektedir. Ülkemizde ise yürürlükte olan mevzuat hükümlerine göre, aileye ilişkin dava ve işler halen genel mahkemelerde görülmektedir. Bu mahkemeler, aileye ilişkin davaların yanı sıra diğer hukuk davalarına da bakmak durumunda olup, ayrıca aile ile ilgili uyuşmazlıkların çözümünde ihtiyaç duyulan, psikolog, pedagog ve sosyal çalışmacı mahkeme bünyesinde bulunmamaktadır. Buysa, mevcut mahkemelerin aile hukukundan doğan dava ve işlerin çözümlenmesinde kendilerinden beklenen işlevi yeterince yerine getirmesine engel olmaktadır. Ayrıca, ... 4721 sayılı Türk Medeni Kanununun özellikle aile hukukuna ilişkin hükümłerinden beklenen amacın gerçekleşmesi bakımından da aile malıkemelerinin kurulması bir ihtiyaç haline gelmiştir."

Ailenin korunmasına ilişkin, Anayasa'nın 41 inci maddesinden başka, yasal diğer düzenlemeler de bulunmaktadır. 14.01.1998 tarihli ve 4320 sayılı Ailenin Korunmasına Dair Kanun, 22.11.2001 tarihli ve 4721 sayılı Türk Medeni Kanunu' nun (TMK) aile hukukuna ilişkin hükümleri, Türk Ceza Kanunu'nun aileye ilişkin hükümleri, aile ve çocuğun korunmasıma ilişkin Türkiye'nin taraf olduğu uluslararası anlaşmalar (örneğin Birleşniş Milletler Çocuk Hakları Sözleşmesi gibi) ve son olarak aile mahkemelerinin kurulmasıma ilişkin 4787 sayılı "Aile Mahkemelerinin Kuruluş, Görev ve Yargılama Usullerine Dair Kanun"u bu kapsamda belirtmek gerekir.

Aile mahkemelerinin kurulmasına ilişkin kanunla, aile hukukundan doğan dava ve işlere bakmak ïzere, özel bir aile mahkemesi kurulması amaçlanmıştır (AMK m. 1.II).

Bilgi çağ olarak kabul edilen çağınızda, bilginin ve uzmanlaşmanın önemi inkâr edilemez bir gerçektir. Bu husus, mahkemelere de yansımış, belirli türdeki uyuşmazlıkları çözmek üzere, özel (ihtisas - uzmanlık)

${ }^{3}$ Hükümet Gerekçesi. 
mahkemeleri kurulmuştur. Genel mahkemelerin yanında, belirli türdeki uyuşmazlıklara bakmak üzere özel mahkemeler kurulması, sosyal (hukuki) ilişkilerde karmaşıklık ve buna bağlı olarak ayrı bir uzmanlık gerektiren uyuşmazlıkların giderek artması ile ortaya çıkan intiyacı karşılamak düşüncesine dayanır. Bu nedenle, özel mahkemeler belirli kişiler arasında ortaya çıkan ve belirli türdeki uyuşmazlıklara bakmak üzere kurulmuş olan birer uzmanlık yargı yeri durumundadırlar ${ }^{4}$.

Aile hukukuna ilişkin uyuşmazhıklar da, bir taraftan sayıları artarken, diǧer taraftan, gün geçtikçe daha karmaşık bir nitelik kazanmaktadırlar; o nedenle, çözüme kavuşturulmaları da uzmanlık gerektirmektedir. Örneğin, yapay döllenme, tüp bebek, kiralık anne, boşanma, özellikle 4721 sayılı Medeni Kanun'la getirilen yeni mal rejiminden kaynaklanan uyuşmazlıkların çözümüu, uzmanlığı gerektiren konular olarak kabul edilmektedir ${ }^{5}$.

Bunların da ötesinde, Hükümet Gerekçesinde belirtildiğ i gibi, aile hukukundan doğan uyuşmazlıkların, ailenin, sosyolojik, psikolojik yapısı ve özellikleri dikkate alınarak, ona göre, bir yargılama yapılması, bunun için de uzman bir mahkemenin kurulması, özel bir düzenlemenin yapılması, zorunludur.

Ülkemiz dışında, diğer pek çok ülkede aile hukukundan doğan uyuşmazlıklar için özel aile mahkemeleri kurulduğunu görmekteyiz. Bunlara, Kuzey Kıbrıs Türk Cumhuriyeti, Fransa, Almanya, Japonya, ABD, İsveç, Yeni Zelanda ömek olarak gösterilebilir'.

Belirtilen nedenlerle, ülkemizde de aile hukukundan doğan uyuşmazlıkları çözümlemek ïzere, özel bir aile mahkemesinin kurulması isabetli olmuştur?.

${ }^{4}$ Arslan. Ramazan Tanrıver, Süha: Yargı Örgütü Hukuku. Ders Kitabı, 2. B., Ankara 2001, s. 41. Medeni yargı alanında faaliyette bulunan diğer ózel mahkemeler, iş mahkemeleri, kadastro mahkemeleri, tüketici mahkemeleri, fikri ve sınai haklar hukuk mahkemeleri, icra tetik mercileri, deniz müsadere mahkemeleridir. Bu mahkemeler hakkında ayruntılt bilgi için bkz. Arslan / Tanrıver s. 64 vd.; Ihtisas mahkemelerine eleştirel bir yaklaşım için bkz. Silme, Şener: Ihtisas Mahkemeleri (Antalya BD. 2002/5-6), s. 18 vd.

${ }^{5}$ Sirmen, Lale / Koçhisarlıoğlu, Cengiz / Tanrıver, Süła / Süral, Nurhan / Tercan, Erdal: Karşılaşıımalı Hukukta Aile Mahkemeleri ve Türkiye'de Aile Mahkemelerinin Kurulmasında Yararlanılabilecek Bir Model (Prof. Dr. Turhan Esener'e Armağan, Ankara 2000 ) s. 2 .

- Bu ülkelerin aile mahkemeleri hakkında ayrıntılı bilgi için bkz. Sirmen / Koçhisarlıoğlu / Tannver / Süral / Tercan s. 2 vd.

"Ancak, bkz. (aşa.) "B" başlı̆̆ı. 


\section{B - AİLE MAHKEMELERININN KURULUŞU}

Aile Mahkemelerinin Kuruluş, Görev ve Yargılama Usullerine Dair Kanun'un 2 inci maddesinin birinci fıkrasına göre, "aile mánkemeleri, Adalet Bakanlığınca Hâkimler ve Savcılar Yüksek Kurulunun olumlu görüşüi alınarak her ilde ve merkez nüfusu yüzbinin üzerindeki her ilçede, tek hakimli ve asliye mahkemesi derecesinde olmak üzere kurulur. Ancak yargı çevresi, Adalet Bảkanlığının teklifi üzerine Hâkimler ve Savcılar Yüksek Kurulunca değiş̧tirilebilir".

Bunà göre, aile mahkemelerinin, sadece, il merkezlerinde ve merkez nüfusu yüzbinin üzerindeki ilçelerde kurulması öngörüldü̆ğünden, bu özel mahkemeler de, yurdun her yerinde kurulmamaktadır. İllerde aile mahkemesi kurulabilmesi için herhangi bir nüfus yogunluğu aranmamıştır. $O$ nedenle, merkez nüfusu yüzbinin altında olan illerde de, aile mahkemeleri kurulacaktır. Zira Kanunda "her ilde" denildiği için ifade mutlaktır. Bu açıdan, nüfusuna bakıılmaksızın, her ilde aile mahkemesi kurulacaktır.

Buna karşılık, yargı teşkilatı açısından esas alınan her ilçe de, aile mahkemesi, kurulmamaktadır. Ilçelerde aile mahkemesi kurulabilmesi için. o ilçenin merkez nüfusu esas alınmış ve merkez nüfusu yüzbinin üzerinde olan ilçelere aile mahkemesi kurulması kabul edilmiştir; buna göre, nüfusu yüzbinin altındaki ilçelerde ise, aile mahkemeleri kurulmayacaktır. Büyüksşehir belediye sınırları içinde kalan ilçeler, o ilin sımırları içinde bulunduğundan, merkez nüfusları yüzbini geçse dahi, o ilçelerde ayrı bir aile mahkemesi kurulması gerekmemektedir.

Aile hukukundan doğan uyuşmazlıkların önemi ve özelliği dikkate alındığında, ıpkı asliye hukuk mahkemeleri gibi, yurdun her yerinde aile mahkemelerinin kurulabilmesi isabetli ve aile mahkemelerinin kurulmasıyla takip edilen amaca uygun bir davranış olurdu. Ancak, ülkemizin içinde bulunduğu ekonomik kriz dikkate alındığında, bunun pek mümkün olamayacağı da açıktır.

Aile mahkemelerinin yargı çevresi, kurulduğu ilin veya ilçenin mülki sınırlarıyla belirlenir. Buna göre, kural olarak, illerdeki aile mahkemelerinin yargı çevresi, o ilin merkez ilçesinin mülki sınırlarıyla, ilçelerdeki aile mahkemelerinin yargı çevresi de, o ilçenin mülki sınırlarıyla sınırlıdır. Ancak, gerek ildeki, gerekse ilçedeki bir aile mahkemesinin yargı çevresi, Adalet Bakanlığı'nın teklifi üzerine Hâkimler ve Savcılar Yükssek Kurulunca de giştirilebilir (AMK m. 2,I).

Aile mahkemeleri, her ilde ve merkez nüfusu yüzbinin üzerindeki ilçelerde kurulması öngörülddüğünden, kuruluş yerleri açısından, 7.11.1979 
tarihli ve 2253 sayılı Çocuk Mahkemelerinin Kuruluşu, Görevleri ve Yargılama Usulleri Hakkında Kanun ile kurulan çocuk mahkemelerine benzemektedir. Gerçekten çocuk mahkemelerinin de, her ilde ve nüfusu yüzbinin üzerindeki ilçelerde kurulması öngörülmüştür. Ancak, aradan geçen zaman içinde Ankara, İstanbul, İzmir gibi birkaç büyük şehir dışında, diğer yerleşim yerlerinde maalesef çocuk mahkemeleri bu güne kadar kurulamamıştır. Umarız, aile mahkemelerinin kuruluşu da, çocuk mahkemelerine benzemez, aynı şekilde birkaç büyük şehirle sınırlı kalmaz, diğer yerleşim yerlerinde de kurulabilir. Aksi takdirde, yurdun belirli yerlerinde kurulan göstermelik birkaç aile mahkemesi ile, aile mahkemelerinin kurulması ile takip edilen amaca ulaşılmış olmaz $z^{8}$.

AMK m.2,II'ye göre, "gerektiǧinde birinci fıkradaki usule göre bir yerdeki aile mabkemesinin birden çok dairesi kurulabilir. Bu durumda, daireler numaralandırılır. Aile mahkemesi kurulamayan yerlerde bu Kanun kapsamına giren dava ve işlere, Hâkimler ve Savcilar Yüksek Kurulunca belirlenen Asliye Hukuk Mahkemesince bakılır."

Buna göre, Adalet Bakanlığı'nca, Hâkimler ve Savcılar Yǘksek Kurulunun olumlu görüşü alınarak, aile mahkemesi kurulan il veya ilçelerden, işi çok olan yerlerde, o yerdeki aile mahkemesinin birden fazla dairesi kurulabilir. Bu durumda, kurulan aile mahkemesinin her dairesine bir numara verilir ve bundan sonra, birinci aile mahkemesi, ikinci aile mahkemesi gibi, her daire (mahkeme) kendi numarasıyla anılır.

Belirtildiği şekilde, bir yerde, birden fazla aile mahkemesi kurulmuşsa, bu mahkemelerin hepsi aynı seviyededir ve aralarındaki ilişki, iş bölümü ilişkisidir. Bu mahkemelerden birisi nöbetçi olur ve mahkemeler arasındaki iş (bölümü) paylaşımı da, o nöbetçi mahkeme tarafından gerçekleştirilir ${ }^{9}$. Buna göre, o yerde aile mahkemesine gelen dava ve işler, bu mahkemeler arasındaki iş bölümüi iliş̧kisi gereğince, işin niteliği dikkate alınmaksızın, sayısal olarak, nöbetçi mahkeme tarafından, mahkemeler arasında eşit olarak paylaştırılır. Bu şekilde, bir yerde birden fazla aile mahkemesi kurulmuşsa, aynı kişilere ilişkin farklı aile mahkemelerinde bakılan dava ve iş olmamalı, bütün aile sorunlarının, aynı aile mahkemesi, (dolayısıyla aynı hakim) tarafından karara bağlanması sağlanmalıdır ${ }^{10}$. Alman hukukunda, bir başka aile sorunu nedeniyle ilk derece mahkemesinin bir başka

\footnotetext{
\& 4077 sayılı Kanun ile kurulan tüketici mahkemeleri açısından da aynı durum geçerlidir.

" Bilgisayar kttllanılan adliyelerde, ditekçe tevzi bürosunda bilgisayara kaydedilir (Yönetmelik m. 18a,II) ve dağıtım oradan yaptiır.

${ }^{10}$ Lüke / Walchshöfer / Wolf : Münchener Kommentar, Bd 3; \$ 803 - I048, München 1992, s.1268.
} 
bölümünde açılmış bir dava varken, evliliğe ilişkin bir dava açılırsa, bu takdirde diğer mahkemenin, bakmakta olduğu davayı, evliliğe iliş̧in davaya bakan mahkemeye kendiliğinden devretmesi gerektiği kabul edilmektedir (Alman Mahkemeler Teşkilatı Kanunu (GVG) § 23b, II) ".

Yukarida belirtildigi gibi, aile mahkemeleri illerde ve merkez nuifusu yüzbinin üzerindeki ilçelerde kurulduğundan, diğer ilçelerde aile mahkemesi kurulamamaktadır. Bu şekilde, aile mahkemesi kurulamayan ilçelerde, aile mahkemesinin görev alanına giren dava ve işler, mecburen, genel mahkeme olarak, o ilçede bulunan asliye hukuk mahkemesince görülecektir. $O$ ilçede bir tane asliye hukuk mahkemesi varsa, aile mahkemesinin görev alanına giren dava ve işler, o asliye hukuk mahkemesince görülecektir. O ilçede, birden fazla asliye hukuk mahkemesi varsa, işte o zaman. AMK m. 2,II'nin son cümlesinde belirtildiği şekilde, bu asliye hukuk mahkemelerinden hangisinin aile mahkemesinin görev alanına giren dava ve işlere bakacağı, Hâkimler ve Savcılar Yüiksek Kurulu'nca belirlenecektir. Örneğin, Hâkimler ve Savcılar Yüiksek Kurulu'nca, "bu gibi yerlerdeki 1 nolu asliye hukuk mahkemeleri, aile mahkemelerinin görev alanına giren dava ve işlere bakacaktır", şeklinde bir karar verilebilir.

Aile mahkemelerinin, AMK m.l'de, "tek hakimli ve asliye mahkemesi derecesinde olmak üzere" kurulacağı belirtilmiştir. Buna göre, her ne kadar, Kanunda "asliye mahkemeleri" deniliyorsa da, bunun "asliye hukuk mahkemeleri" olarak anlaşılması dogaldır. O nedenle, aile mahkemeleri, asliye hukuk mahkemesi derecesinde, medeni yargiya dahil özel mahkemelerdir. Bu tespite bağlı olarak, aile mahkemelerinin, bir üst derece, kontrol mahkemesi olmayıp; aile hukukundan doğan dava ve işler için, bir ilk derece, hüküm mahkemesi olduğu da belirtilmelidir. Bazı yabancı ülkelerde, örneğin Almanya'da aile mahkemeleri, sulh hukuk mahkemesi derecesinde, onun bir bölümü olarak kurulmuşken ${ }^{12}$, Fransa'da asliye hukuk mahkemesi derecesinde öngörülmüştür ${ }^{13}$.

Aile mahkemelerinin, asliye hukuk mahkemesi derecesinde olduğg kabul edilmesine rağmen, tek hakimli olması benimsenmiştir. Oysa, asliye hukuk mahkemeleri bilindiği gibi, 469 sayılı Kanuna göre uç hakimli, toplu mahkeme olarak kabul edilmiştir (469 s.K. m.1). Ancak, hakim azlığ nedeniyle. 469 sayll Kanunun geçici maddesi uyarınca, asliye hukuk mahkemeleri tek hakjmle görev yapmaktadırlar. Bu durum, yani asliye hukuk mahkemelerinin tek hakimle görev yapması geçicidir, fiili engele.

"Tercan. Erda1: Temel Özellikleriyle Alman Aile Mahkemeleri (Turkiye Noterler Birliği Hukuk Dergisi. Sayı: 100, 15 Kasım 1998), s. 31 .

12 Tercan 8.30 .

1. Sirmen / Koçhisarlıoglu / Tanrıver / Süral / Tercan s. 4. 
hakim azlığına dayanmaktadır. Maalesef, bu durum, 469 sayılı Kanunun yürürlüğge girdiği 1924 tarihinden beri değiştirilememiş, asliye hukuk mahkemeleri, bu gün de halâ tek hakimle görev yapmaya devam etmektedir. Buna göre, asliye hukuk mahkemeleri kural olarak üç hakimli mahkemelerdir. Ancak, geçici olarak (istisnaen) tek hakimle görev yapmaktadırlar. Aile mahkemeleri kurulurken, bu mahkemelerin bir taraftan asliye hukuk mahkemesi derecesinde olması, diger taraftan da, tek hakimli olması kabul edilmiştir. Bu durumda da, asliye hukuk mahkemelerinin üç̧ hakimli olmasını öngören, asıl kurala (469 s.K.m.1) değil, tek hakimli olmasını öngören geçici maddeye (469 s.K.geçici madde) atıf yapılarak, asıl kurala aykırı davranılmıştır veya konunun diğer yönüyle, geçici madde asıl kural haline dönüştürülmüştür. Bununla beraber, Ülkemizin içinde bulunduğu durum dikkate alındığnda, aile mahkemelerinin tek hakimli olarak kurulması kanaatimce de isabetli olmuştur. Nitekim, yabancı illkelerde de, aile mahkemelerinin tek hakimli olmasını öngören ülkeler vardır. Örneğin, Kuzey Kıbrıs Türk Cumhuriyeti, Fransa ve Almanya' da ${ }^{14}$ aile mahkemeleri tek halimlidir. Buna karşılık, İsveç'de, evlilik birliği ve nafaka davaları bir hakim ve üç yardımcıdan oluşan mahkeme tarafından karara baglanmaktadir ${ }^{15}$.

Bilindiği gibi, özel mahkeme ile genel mahkemeler arasındaki ilişki bir görev ilişkisidir ${ }^{16}$. Aile mahkemeleri de, bir özel mahkeme olduğundan, aile mahkemeleri ile asliye hukuk mahkemeleri arasındaki ilişki, keza, aile mahkemeleri ile sulh hukuk mahkemeleri arasındaki ilişki bir görev ilişkisidir. Bir yerde, özel mahkeme olarak aile mahkemesi kurulmuşsa, aile hukukundan doğan dava ve işler, artık özel mahkeme olarak aile mahkemesince görülür; genel mahkeme olarak asliye hukuk mahkemesinde görülemez. Bu görev ilişkisine, gerek aile mahkemesi, gerek asliye hukuk mahkemesi re'sen dikkat etmek zorundadır. Aile mahkemesinin görev alanına giren bir dava, asliye hukuk mahkemesinde açılırsa, asliye hukuk mahkemesi görevsizlik kararı vermelidir ${ }^{17}$.

Buna karşılık, nüfusu yüzbinin alındaki bir ilçede, aile mahkemesi kurulmayacağından, bu gibi, ayrı bir aile mahkemesi olmayan yerlerde, aile mahkemesinin görev alanına giren dava ve işler de, genel mahkeme olarak, orada bulunan asliye hukuk mahkemesinde görülecektir. Böyle bir durumda,

\footnotetext{
${ }^{14}$ Tercan 5.6 .

${ }^{15}$ Sirmen / Koçhisatlıoğlu / Tanrıver / Süral / Tercan s. 2 vd.. s.21.

"'r Kuru, Bakj / Arslan, Ramazan / Yılmaz, Ejder : Medenî Usul Hukuku Ders Kitabr, 14.B., Ankara 2002 s. 90; 130 vd.; 226; Pekcantez, Hakan / Atalay, Oguz / Özekes, Muhammet : Medeni Usul Hukuku, 2.B.,Ankara 2001, s.86.

${ }^{17}$ Aile mahkemesi kurulan yerlerde bu mahkemeler faaliyete geçtiğinde, yargı çevresi içerisinde ve görev alanına giren sonuçlanmamış dava ve işler, yetkili ve görevli aile mahkemesine devredilir (AMK Geçici madde 1).
} 
davanın, asliye hukuk mahkemesinde açlırken, aile mahkemesi sıfatıyla açılması zorunlu değildir: asliye hukuk mahkemesi olarak açılsa da, mahkeme görevsizlik kararı vermeyip, davayı kararı bağlamalıdır. Yalnız bu halde, genel máhkemenin, özel makkeme (aile mahkemesi) sıfatıyla, davaya baktığını belirtmesi gerekli ve yeterlidir ${ }^{1 *}$. Yukarıda belirtildiğ gibi, bu gibi yerlerde, birden fazla asliye hukuk mahkemesi varsa, bunlardan hangisinin aile hukukundan doğan dava ve işlere bakacağı, Hâkimler ve savcılar Yüksek Kurulu'nca belirlenecektir. Belirlenen bu asliye hukuk mahkemesinde, aile hukukunden doğan dava ve işler, tıpkı bir aile mahkemesi gibi hareket edilerek, yani aynı usul ${ }^{14}$ uygulanarak, karara bağlanacaktır.

\section{C - AİLE MAHKEMESI GÖREVLIILERI}

Diğer mahkemelerde olduğu gibi, aile mahkemelerinin başında bir hakim, bir yazı işleri müdürü ile yeteri kadar personel bulunur (AMK m. 2,III). Diğer mahkemelerden falklı olarak, aile mahkemelerinde ayrıca, psikolog, pedagog ve sosyal çalışmacı gibi, uzmanların da bulunması kabul edilmiştir (AMK m. 5). Aile mahkemesi görevlilerine daha yakından bakmak yararlı olacaktır:

\section{I - Aile Mahkemeleri Hakimleri}

"Aile mahkemeleri hâkimlerinin nitelikleri ve atanmaları" başlığını taşıyan AMK m. 3'e göre, "aile mahkemelerine, atanacakları bölgeye veya bir alt bölgeye hak kazanmış. adlî yargıda görevli, evli ve çocuk sahibi, otuz yaşını doldurmuş ve tercihan aile hukuku alanında lisansüstui eğitim yapmış olan hâkimler arasından Hâkinller ve Savcılar Yüksek Kurulunca atama yapılır." Bu hüküm çerçevesinde, aile mahkemelerine atanacak hakimlerin şu niteliklere sahip olması gerekmektedir:

1 - Aile Mahkemelerine Atanacak Hakimlerin. Hukuk Fakültesi Mezunu Otması ve Adli Yargıda Görevli Olması Gereklidjr

Yukarıda, aile mahkemelerinin kuruluşunu incelerken, AMK m. 2 gereğince, aile mahkemelerinin tek hakimli olduğunu belirtmiştik. Şu halde, AMK m.2 ve 3'e göre, aile mahkemelerinin başında bir hakim bulunur. Bu hakim, adlî yargıda görev yapan diğer mahkemelerde görevli hakimlerde olduğu gibj, hukuk fakültesindeı mezun olanlar arasından seçilecektir. O nedenle. idari yargıda olduğu gibi, hukuk fakültesinden mezun olmayıp,

\footnotetext{
is Kuru. Baki: Hukuk Muhakemeleri IIsulü, C.I, 6.B.. İstanbul 2001 (kısaltma Kuru HMU 1), s. 720 .

${ }^{14}$ Aile malıkemelcrinde uygulanacak yargllama usulü için bk\%. aşa. "E" başlığ
} 
siyasal bilgiler fakültesi veya diger faküItelerden mezun olanlar veya aile ile ilgili diģer alanlarda uğraşanlar, aile mahkemesine hakim olarak atanamazlar. Nitekim, AMK m. 3'de aile mahkemelerine atanacak hakimlerin, adli yargıda görevli hakimler arasından seçilerek atanacağı açıkça öngörüilmüş̧ür. Bilindiği gibi, adli yargıda, hakim olabilmek için de, hukuk fakültesi mezunu olmak zorunludur (Hakimler ve Savcilar Kanunu m.8).

\section{2 - Aile Mahkemelerine Atanacak Hakimler, Evlenmiş Olmalıdır}

Aile mahkemelerine atanacak hakimlerin, halen adli yargıda görevli olması, ayrıca "evli" olması da gereklidir. Burada, AMK m.3 hükmünün lâfzından, aile mahkemesine atanacak hakimin, halen evli ve bu evlilikten en az bir çocuk sahibi olması gibi, bir zorunluluk anlaşılmaktadır. Kanaatimce, aile mahkemesine atanacak hakim, evlenmiş ve boşanmış da olsa, diğer özellikleri uygunsa, aile mahkemesine hakim olarak atanabilmelidir. Hükmün lâfzı ön plâna çıkartılıp, halen evli olmak zorunlu olmamalıdır. Burada önemli olan, aile mahkemesine hakim olarak atanacak kimsenin, evlilik ve aile kurumunu bizzat yaşayarak, o konularda bilgi ve tecrübe sahibi olması, kendi evliliği nedeniyle sahip olduğu bu bilgi ve tecrübeleri, aile mahkemesi hakimi olarak, baktığg dava ve işlerde kullanabilmesini sağlamaktır. Bu durum dikkate alındığında, evlenmiş ve boşanmış hakimlerin de, aynı bilgi ve tecrübeye sahip oldukları, bunları, baktıkları dava ve işler de kullanabileceklerini söylemek mümkündür.

Aynı durum, eşi öldúğüi için, evliliği sona eren hakimler için de geçerlidir; bu gibi hakimler de, diğer özellikleri uygunsa, aile mahkemesine hakim olarak atanabilmelidir.

\section{3 - Aile Mahkemesine Atanacak Hakimlerin, Çocuk Sahibi Olması Gereklidir}

AMK m. 3 hükmü gereğince, aile mahkemelerine atanacak hakimlerin, ayrıca çocuk sahibi olmaları da gerekmektedir. Söz konusu hükümde her ne kadar, "çocuk sahibi" olmak şeklinde tekil bir ifade kullanılmışsa da, birden fazla çocuğu olan hakimlerin de, aile mahkemesine hakim olarak atanması mümkündür. Burada, "çocuk sahibi olmak" şartını, "en az bir çocuk sahibi olmak" şeklinde anlamak uyun olur.

Bu çocuğun, hakimin kendi evliliğinden olması doğal olanıdır. Ancak, hüikümde açıkça bir sınırlama olmadığından, çocuğu olmayan hakim, taşıyıcı anne veya diğer yöntemlerle çocuk sahibi olmuşsa yahut evlât edinmiş ise, bu takdirde, aile mahkemesine hakim olarak atanabilmek için gerekli olan "çocuk sahibi olmak" ફ̧artı, gerçekleşmiş sayılmalıdır. Zira, burada da 
önemli olan, hakimin bizzat çocuk yapma yeteneğine sahip olup olmadığı değil, bir çocuğun bakımını ve sorumlulığunu üzerine alıp, çocukları yakından tanıyıp tanımadığı ve o konuda doğrudan bilgi sahibi olup olmadığıdır: keza, hakimin, bakımını ve sorumluluğunu üstlendiği, doğrudan ilgilendiği o çocuk nedeniyle sahip olduğu bilgi ve tecrübenin, aile mahkemesi hakimi olarak, öniine gelen dava ve işlerde kullanabilmesine imkân vermek, böylece, aile ve çocuğun yapısına, psikolojisine dăha uygun kararlar verilmesini sağlamaktır. Bu durum da, taşıyıcı anne veya diğer yöntemlerle çocuk sahibi olmuş veya evlât edinmiş hakimler için de gerçekleşebilir. O nedenle, bu şekilde çocuk sahibi olmuş hakimlerin de, aile mahkemesine hakim olarak atanabilmesi mümkün olmalıdır.

\section{4 - Aile Mahkemelerine Atanacak Hakimlerin, Otuz Yaşını Doldurmuş Olmaları Gereklidir}

AMK m. 3 gereğince, aile mahkemesine hakim olarak atanacak kimselerin, otuz yaşını doldurmuş olmaları da gereklidir. Kanun koyucu, aile mahkemesine atanacak hakimler için otuz yaşını doldurmuş olma şartını öngörerek, yaşça belirli bir olgunluğa ulaşmış olmayı zorunlu görnüusşür. Gerçekten, yaşça belirli bir olgunluğa ulaşmış olanlar, aile ve çocuk gibi, hassas konularda, kural olarak, daha makul ve mantıklı hareket edebilirler. Bu açıdan, belirli bir yaş sınırı öngörmek isabetli olmuştur. Belki bu yaş sınırı, otuz değil de, otuzbeş olsayd, daha isabetli olabilirdi.

5 - Aile Mahkemelerine Atanacak Hakimler Açısından, Aile Hukuku Alanında Lisansüstü Eğitim Yapmış Olmak Tercih Sebebidir

Aile mahkemesine hakim olarak atanacak kimseler için zorunlu olmamakla birlikte, AMK m. 3, "aile hukuku alanmda lisansüstü ełitim yapmış olmayı" bir tercih sebebi olarak belirtmiştir. Aile mahkemesine atanacak hakimler için, aile hukuku alanında lisans üstij eğitim olarak, yüiksek tisans veya doktora yapmış olmayı, tercih sebebi saymak isabetli olmuştur. Gerçekten, ilgili alanda daha fazla eğitim görmenin, o alanda uzmanlaşmanın yararı açıtır. Ancak, sosyal bilimler enstitüsü bünyelerinde, münhasıran aile hukuku alanında yüksek lisans veya doktora programları açılmamaktadır. Özel hukuka bağlı olarak, aile hukukunun da dahil olduğu genel olarak medeni hukuk alanında yüksek lisans veya doktora programı açılmaktadır. Bu durunda, sadece aile hukuku alanında yüksek lisans veya doktora yapmak söz konusu olamaz. Peki, kanundaki "aile hukuku alanmda lisansüstii eğitim yapmuş olma" şartı nasıl gerçekleştirilecektir? Kanatitimce, bu günkü lisansüstii eğitim programı çerçevesinde, medeni hukuk alanında veya aile hukukuyla ilişkili diğer alanlarda, örneğin medeni usul hukukunda yüksek lisans veya doktora yapan bir kimse, aile hukukuna ilişkin bir konuda yüksek lisans veya doktora tezi yazmış ve kabul edilmişse, böyle bir 
kimseyi "aile hukuku alanında lisansüstä eğitim yapmı̧" saymak mümkündür.

Yurtdışında, aile hukuku alanında belirtildiği şekilde yüksek lisans veya doktora yapılıp, Türkiye'de denklik belgesi alınmışsa, yine AMK m.3’ün belirttiği aile hukuku alanında lisansüstü eğitim yapmış olma şartı gerçekleşmiş sayılmalıdır.

\section{II - Yazı İşleri Müdürii, Katip ve Mübaşir}

AMK m. 2, III, bu konuya ilişkin olarak, "aile mahkemelerinde bir yazı işleri müdürü ile yeteri kadar personel bulunur" demektedir.

Diğer mahkemelerde olduğu gibi, aile mahkemelerinde de, bir kalem teşkilatı bulunur. Bu kalem teşkilatının başında bir yazı işleri müdürü, yeteri kadar zabıt katibi ve bir de mübaşir bulunmalıdır. Bu görevliler hakkında, aile mahkemeleri açısından ayrıca bir özellik gerekmediğinden, ayrıntıya girilmeyecektir ${ }^{20}$. Bununla birlikte, iyi işleyen bir kalem teşkilâtı, hakimin işini büyük ölçiide kolaylaştıracağından, en azından aile mahkemesi yazı işleri müdürlerinin yetişmiş personel arasından seçilmesi, özellikle, bu konuda adalet meslek yüksek okullarından mezun olanların tercih edilmesinin yararlı olacağım belirtmek isterim.

\section{III - Psikolog, Pedagog ve Sosyal Çalışmacı}

"Aile mahkemeleri bünyesinde bulunan uzmanlar" başlığını taşıyan AMK m. 5'e göre, "her aile mahkemesine, ..... Adalet Bakanlığınca, tercihan; evli ve çocuk sahibi, otuz yaşını doldurmuş ve aile sorunları alanında lisansüsttï eğitim yapmış olanlar arasından, birer psikolog, pedagog ve sosyal çalışmacı atanır."

Bu hükümle, her aile mahkemesine, bir tane psikolog, bir tane pedagog ve bir tane de sosyal çalışmacı olmak üzere, en az üç tane uzman atanması kabul edilmiştir. Görüldüğüi gibi, bu uzmanlar, birbirine alternatif değil, yani biri olmazsa, diğeri atanacak şekilde değil, bir aile mahkemesine üçünün birlikte atanması kabul edilmiştir. O nedenle, kural olarak, her aile mahkemesinde bu uzmanlardan birer tane bulunacaktır ${ }^{2 \prime}$.

${ }^{21}$ Bu görevliler hakkında daha geniş bilgi için bkz. Arslan / Tanrıver s.194 vd.

${ }^{21}$ Bu uzmanlardan, her aile mahkemesinde birer tane bulundurmak oldukça zor görünmektedir. Ayrıca, çocuk mahkemelerinde de bulunması kabul edilen bu uzmanlardan uygulamada, mahkemelerin gerektiği şekilde yararlandığı da söylenemez. 
Bu uzmanların, Adalet Bakanlığınca, aile mahkemesine kadrolu ve sürekli olarak atanmaları kabul edilmiştir.

Aile mahkemesi hakiminde olduğu gibi, mahkemeye atanacak uzmanların da belirli niteliklese sahip olması Kanun koyucu tarafundan tercih sebebi sayılmıştır. Aile mahkemesine atanacak bu uzmanların. evli ve çocuk sahibi olmaları, otuz yaşını doldurmuş olmaları, aile sortuları hakkında lisansüstü eğitim yapmış olmaları istenmiştir. Ancak bu nitelikler, zorunlu olmayıp, sadece tercih sebebidir. O nedenle, bu niteliklere sahip olmatyan bir uzman da, gerekli görülürse, aile mahkemesine atanabilecektir. Buna karşılık, aile mahkemesine atanacak hakimler için evli ve çocuk sahibi olmak ve otuz yaşını doldurmak zorunlu iken. lisansüstü eğitim bir tercilı sebebi salyılmıştır

Aile mahkemesinde görülmekte olan dava veya iş nedeniyle, psikolog. pedagog ve sosyal çalışmacı dışında, başka bir uzmanlık dałına ihtiyaç duyulması hallerinde, diğer kamu kurum ve kuruluşlarında çalışanlar veya serbest meslek icra edenlerden yararlanılır (AMK m. 5, Il). Mabkemeye kadrolu, olarak atanan psikolog, pedagog ve sosyal çalışmacı, normal devlet memuru olarak maaşını alısken, bunların dişında, diģer kurumlarda görev yapanlar veya serbest çalışanlardan yardım istenirse, bu takdirde, bunlara ayrıca ücret ödenmesi gereklidir. Bu ödenecek ïcretin, taraflara yükletilmemesi, tıpkı mahkemeye kadrolu olarak atanan psikolog, pedagog ve sosyal çalışmacının ücreti gibi. Devlet tarafından ödenmesi gereklidir. Aksi takdirde, ayn konumdaki uzmanlardan mahkemede kadrolu olarak bulunanların ücretini Devlet, kadrosu bulunmayanları ise taraflara ödettirmek çelişki olacağı gibi, eşitlik ilkesine de aykırı olur.

AMK m. 5,II’ye göre, "bu görevlilerin bulunmaması, iş durumlarınıı müsait olmaması veya görevin bunlar tarafından yapılmasında hukukî veya fiilî herhangi bir engel bulumması ... hallerinde diğer kamu kurum ve kuruluşlarında çahışanlar veya serbest meslek icra edenlerden yararlamılır." Bu görevlilerin, görevlerini yapmalarna engel olan, özellikle hukuki engel bulunup bulunmadığını, ilgilinin görev yaptığı aile mahkemesi inceleyip karara bağ̣lanalıdır.

Yine bu uzmanlar, kendileriyle doğrudan veya dolayh olarak iliş̧ili olan dava ve işlerde görev almamalıdır. Zira ilişkili oldukları dava işlerde tarafsız davranamazlar. O nedenle, AMK m. 5,III'e göre. Hukuk Usulij Muhakemeleri Kanunu nda (HUMK) dizenlenen hakimin reddi sebeplerine göre, bu uzmanlarm da reddedilmesi mümkündür. Kanunda her ne kadar, sadece hakimin reddi sebeplerinden (HUMK m. 29) söz edilerek, uzmanların reddedilebileceği kabul edilmişse de, niteliğine aykırı olmamak kaydıyla. hakimin yasaklılık hallerinin (HUMK m. 28) uzmanların şahsında 
gerçekleşmesi halinde de, uzmanların o dava ve işte görev yapmaması ve reddedilmeleri mümkün olmalıdır. Uzmanların reddedilmesi halinde, ret talebi, uzmanların görev yaptığı aile mahkemesine yapılmalıdır. Ret talebi, taraflarca yapılabileceği gibi, ilgili uzman da kendisi çekinme talebinde bulunabilmelidir. Çekinme talebi de yine aynı mahkemeye yapılmalıdır. Gerek taraflarca yapılan ret talebi, gerekse ilgili uzmanca yapılan çekinme talebi, dava veya işe bakan, aynı aile mahkemesince incelenip karara bağlanır.

Aile mahkemesine atanan bu uzmanların hangi görevleri yapacaklari, AMK m. 5'de belirtilmiştir. Bu görevler şunlardır:

1. Davanın esasına girilmeden önce veya davanın görülmesi sırasında, mahkemece istenen konular hakkında taraflar arasındaki uyuşmazlık nedenlerine ilişkin araştırma ve inceleme yapmak ve sonucunu bildirmek,

2. Mahkemenin gerekli gördügü hallerde duruşmada hazır bulunmak, istenilen konularla ilgili çalışmalar yapmak ve görüş bildirmek,

\section{Mahkemece verilecek diğer görevleri yapmak.}

Görüldiiğü gibi, bu görevler, davanın açılmasından sonra, mahkemenin göreceği lüzum üzerine, taraflar arasındaki uyuşmazlığın ne olduğu, neden kaynaklandığı gibi konularda, uzmanların araştırma yapmaları, bu konular hakkında vardıkları sonuçları hakime bildirmelerine ilişkindir. Hakim, uzmanların yardımıyla tespit ettiği uyuşmazlık nedenlerini değerlendirip. öncelikle tarafların uzlaşmalarını sağlamaya çalışacaktır; bu mümkün olmazsa, bu kez, uyuşmazlık nedenleri, dikkate alınarak, yargılama yapılıp ona göre bir karar verilmesi saglanacaktır.

Uzmanlar, mahkemenin gerekli gördüğï hallerde, duruşmada hazır bulunmak, istenilen konularla ilgili çalışmalar yapmak ve görüiş bildirmekle de yükümlüdürler. Örneğin, taraflarm dinlenmesi veya isticvabına (HUMK m. 230-235) karar verilmişse, sorgulama esnasında uzmanların da hazır bulunması, tarafların psikolojik durumunu, vb hususları tespit etmek. açısından, yararlı olabilir; bu konularda hakime yardımcı olabilirler.

Uzmanlar, ayrıca mahkemenin verdiği diğer görevlerì yerine getirirler. Bu bağlamda, AMK m.6'ya göre, hakimin, koruyucu, eğitici ve sosyal önlemlere karar vermesi halinde, verilen bu kararların takip ve yerine getirilmesinde bu uzmanlardan biri veya bir kaçı görevlendirilebilir (AMK m. 6,II) . 
Aile mahkemesine atanan psikolog, pedagog ve sosyal çalışmacıların hukuki niteliği acaba nedir ? Bu uzmanlar, bilirkişi sayılabilirler mi ?

Belirtmek gerekir ki, bu uzmanlar da, bazı hallerde tıpkı bilirkişi gibi, mahkemeye görüş̧ bildirseler de, bunları, HUMK m. $275 \mathrm{vd}$. anlanunda bilirkişi saymak mümkün değildir. Zira, öncelikle. HUMK m. 275 gereğince, bilirkişiye, uyuşmazlığın çözümii için önem taşıyan ve ispatı gerekli olan vakıalar hakkında özel ve teknik bilgi gerekiyorsa başvurulur: oysa uzmanlara, taraflar arasındaki uyuşmazlık nedenlerini araşıtırmăları için veya duruşmalarda hazır bulunup istenilen konularla ilgili çalışmalar yapmaları için başvurulur: yahut mahkemenin verdiği koruyucu, eğitici ve sosyal önlemlere ilişkin kararlarının yerine getirilmesinde yardım istenir. Göriilđưưưu gibi, bilirkişiye üzerinde uyuşmazlık bulunan vakıalar için başvurulurken, uzmanlara, uyuşmazlık nedenlerini araştırmaları için başvurulmaktádır. Bilirkişiye re'sen veya talep üzerine başvurulabilirken, uzmanlara, hakkim re'sen başvurabilmektedir.

Bilirkişi raporu, üzerinde uyuşmazlık bulunan vakıaların ispatı için başvurulan bir ispat aracı, delil iken; uzmanlar, sadece uyuşmazlik nedenlerini araştırdıklarından ve bu konuda görüş bildirdiklerinden, onların bildirdiği görüş delil sayılamaz. Uzmanların buradaki faaliyetini, davanın aydınlatılması için hakime yardımcı olma şeklinde nitelemek mümkündür. Zira, uzmanlar olmasa idi dahi, hakim, vakıalar ve uyuşmazlık nedenlerini zaten açıklığa kavuşturmak zorunda idi. Bu durum, hakimin, davayı aydınlatma yüküimlülïğ̈ünün (HUMK m. 75, II;m. 213) bir gereğidir ${ }^{2}$.

Bilirkişi raporuna taraflar itiraz edebilirken (HUMK m.283), uzmanların hakime bildirdikleri görüşleri hakkında, tarafların itiraz. edebileceğine ilişkin kanunda bir açıklık yoktur. Bununla birlikte, taraflar, hakimden, uzmanların bildirdikleri görusşlerin eksik yahut hatalı olduğunu ileri sürerek, bunların düzeltilmesini, tamamlanmasını, doğgusunun araştırılmasın isteyebilmelidirler.

Uzmanlar, Adalet Bakanlığınca önceden atanmış kadrolu devlet memuru niteliğindedir, bu açidan, resmi bilirkişilerle paralellik arzetseler de. ihtiyari bilirkişiler, HUMK m. 275 vd.na göre, davanın açılmasından sonta, mahkemece tayin edilir. Bu açıdan uzmanlarla, ihtiyari bilirkişi arasında yine farklılık vardır. Ayrıca, bilirkişiye başvurulmasına karar verildiğinde, bilirkişi seçimi öncelikle taraflara aittir, taraflar anlaşamazlarsa, hakim

\footnotetext{
"Alangoya, Yavuz: Medeni Usul Hukuku Esasları, 2. B., Istanbul 2001. s. 288 vd: Alangoya. Yavuz: Mcdeni Usul Hukukunda Vakialarin ve Delillerin Toplanmasma İlsskin Ilkeler, İstanbul 1979, s. 135 vd. Alangoya (Vakiaların ve Delillerin Toplanması s. 135). bu yolla, hákimin doğru bir hükme varma olasılığıının önemli ölçüde artacağını da belirtncktedir.
} 
re'sen seçer (HUMK m. 276,I). Oysa, uzmanlar açısından böyle bir durum geçerli değildir, tarafların uzmanlanı seçmesi söz konusu olamaz.

Bu uzmanların maaşları Devlet tarafından ödenir, bu maaşlar daha sonra davayı kaybeden tarafa yükletilmez; oysa bilirkişinin ücretini mahkeme tayin eder (HUMK m. 285) ve davanın taraflarınca ödenir ve daha sonra davayı kaybeden tarafa yükletilir (HUMK m.417).

Belirtilen bu ve benzeri farkltlardan dolayı, aile mahkemesine atanan uzmanların, HUMK m. 275 vd. anlamında bilirkişi olmadığı, davanm açıklığa kavuşturulması, hakimin, atlenin ve çocukların durumları hakkında daha iyi bilgi sahibi olması ve bunların durumuna uygun kararlar verilmesini ve verilen kararların, ailenin ve çocuğun durumuna uygun olarak yerine getirilmesini sağlamak için hakime yardımcı personel olduğu sonucuna varmak mümkündür.

\section{D - AILE MAHKEMELERINIIN GÖREVİ VE YETKİSI \\ I - Görev}

Aile mahkemeleri, yukarıda da belirtildiği gibi, aile hukukundan doğan dava ve işleri görmek üzere kurulmuşlardır (AMK m. 1). Bu genel çerçeve içinde, aile mahkemelerinin görev alanına ilişkin olarak, AMK'da üç ayrı hïküm bulunmaktadır. Bunlar: AMK'nun. 4,6 ve 9 uncu maddeleridir.

\section{1 - AMK m.4'de Belirtilen Görevler}

AMK m. 4'de üç bent halinde aile mahkemesinin bakacağ dava ve işler belirtilmiştir. Bu hüküm şu şekildedir:

“1. 22.11.2001 tarihli ve 4721 sayllı Türk Medeni Kanununun İkinci Kitabı ile 3.12.2001 tarihli ve 4722 sayılı Türk Medeni Kanununun Yürürlüjüi ve Uygulama Şekli Hakkında Kanuna göre aile hukukundan doğan dava ve işler,

2 . 20.51982 tarihli ve 2675 sayılı Milletlerarası Özel Hukuk ve Usul Hukuku Hakkında Kanuna göre aile hukukuna ilişkin yabancı mahkeme kararlarının tanıma ve tenfizi,

3. Kanunlarla verilen diğer görevler" i yerine getirir.

Buna göre, aile mahkemeleri, TMK'nun aile hukukuna ilişkin ikinci kitabında düzenlenen bütün konulara bakmakla yükümlüdür. Bu bağlamda aile mahkemesinin görev alanına giren konulara genel olarak başlıklar halinde değinilecek olursa, bunlar; nişanlılık, özellikle nişanını bozulması halinde istenen maddi ve manevi tazminat davaları, hediyelerin geri verilmesine ilişkin davalar, evlenmeye ilişkin talepler, evliliğin butlanına ilişkin davalar, boşanma ve ayrılık davaları, boşanma halinde tazminat ve 
nafaka istekleri, evlilik birliğinin korunmasına ilişkin önlemler, mal rejimine ilişkin uyuşmazlıklar, soy bağına ilişkin uyuşmazlıklar bu arada, babalık davası ve tanıma, evlat edinme, velayet ve vesayete ilişkin dava ve işlerdir.

Belirtmek gerekir ki, bu konulara ilişkin dava ve işlerden, konusu para veya para ile ölçülebilen davalarda, HUMK m.8'deki parasal sını (400 milyon TL) dikkate alınmaksızın, aile mahkemeleri görevlidir. Zira. AMK m.4/1 "de kullanılan ifade mutlak olup, TMK'nun "aile hukuku" baışlıklı ikinci kitabında düzenlenen her türlü dava ve iş, ayırım yapılmaksızın aile mahkemesinin görev alanına verilmiştir. Buna göre, örneğin, nişanın bozulması halinde açılan maddi veya manevi tazminat davaları (TMK $\mathrm{m}$. 120,121 ) veya hediyelerin geri verilmesine ilişkin davalar (TMK m. 122) için, talep edilen miktar veya değer dikkate alınmaksızın, aile mahkemeleri görevlidir.

AMK m.4/2 gereğince, Milletlerarası Özel Hukuk ve Usul Hukuku Hakkında Kanuna göre aile hukukuna ilişkin yabancı malikeme kararlurının tanıma ve tenfizi de aile mahkemelerinin görev alanına verilmiştir. Acaba burada geçen "aile hukukuna ilişkin yabancı mahkeme kararları" ifadesinin kapsamı nedir? Kanaatimce, yukarıda TMK'nun ikinci kitabında belirtilen dava ve işler ölçütü, burada da uygulanmalı ve bu konulara ilişkin yabancı mahkemelerce verilen kararların tanıma ve tenfizi aile mahkemelerince incelenmelidir. Ancak, örneğin nişanın bozulması halinde istenen tazminat davaları gibi, doğrudan aile hukukuna ilişkin olmayıp, malvarlığına yönelik davalardaki yabancı mahkeme kararlarının tanıma ve tenfizinde, görevli mahkemenin genel hükümlere (MÖHUK m. 34 vd.) göre belirlenmesi uygun olur.

AMK m.4/3'e göre aile mahkemeleri, Kanumlarla verilen diğer görevleri de yerine getirir. Bu bağlamda, örneğin, 14.01.1998 tarihli ve 4320 sayılı Ailenin Korunmasma Daił Kanun'un 1 inci maddesinde belirtilen önlemleri ${ }^{23}$; Türkiye'nin taraf olduğu, aile, kadın ve çocuğun korummasına ilişkin uluslararası anlaşmalardan doğan uyuşmazlıkları belirtmek mümkündiùr.

\section{2-AMK m. 6`da Belirtilen Ö́nlemler}

"Koruyucu, eğitici ve sosyal önlemler" başlı̆̆ımı taşıyan AMK m. 6" ya göre: "Aile mahkemesi diğer kanunlardaki hükümler saklı kalnak üzere görev alanına giren konularda:

\footnotetext{
${ }^{23}$ Bu önlemler hakkında bkz. aşa. D I. 3 ve F, II Nolu başłıklar.
} 
1. Yetişkinler hakkında;

a) Evlilik birliğinden doğan yüikümlüliikleri konusunda eşleri uyararak, gerektiğinde uzlaştırmaya,

b) Ailenin ekonomik varlığının korunması veya evlilik birliğinden doğan malî yüikümlülüklerin yerine getirilmesine ilişkin gerekli önlemleri almaya,

c) Resmî veya özel sağlık veya sosyal hizmet kurumlarına, huzur evlerine veya benzeri yerlere yerleştirmeye,

d) Bir meslek edinme kursuna veya uygun görülecek bir eğitim kurumuna vermeye,

2. Küçükler hakkında ;

a) Bakım ve gözetime yönelik nafaka yükümlülił̆ğù konusunda gerekli önlemleri almaya,

b) Bedensel ve zihinsel gelişmesi tehlikede bulunan veya manen terk edilmiş halde kalan küçüğü, ana ve babadan alarak bir aile yanına veya resmî ya da özel sağlık kurumuna veya eğitimi güç çocuklara mahsus kuruma yerleştirmeye,

c) Çocuk mallarının yönetimi ve korunmasına ilişkin önlemleri almaya,

d) Genel ve katma bütçeli daireler, mahallî idareler, kamu iktisadî teşebbüsleri ve bankalar tarafından kurulmuş teşekkül, müessese veya işletmelere veya benzeri işyerlerine yahut meslek sahibi birinin yanına yerleştirmeye,

Karar verebilir.

Aile mahkemesince verilen bu kararların takip ve yerine getirilmesinde 5 inci maddeye göre atanan uzmanlardan biri veya birkaçı görevlendirilebilir. Bu kararlara uyulmaması halinde Hukuk Usulï Muhakemeleri Kanununun 113/A maddesi uygulanır."

Görüildüğü gibi, aile mahkemeleri, AMK m.6/1, a ve b alt bentleri gereğince, evli yetişkinler hakkında evlilik birliğinden doğan görevleri hakkında onları uyarmaya, eşler arasında bu konuda uyuşmazlık varsa eşleri uzlaştırmaya; ailenin ekonomik varlığının korunması veya eşler evlilik birliğinden doğan mali yükümlülüklerini yerine getirmiyorsa bunu saglamak için gerekli önlemleri almaya yetkilidir. Yine $\mathrm{m} .6 / 1$, c ve $d$ alt bentleri 
gereğince evli veya bekar yetişkinler hakkında da onları, sağlık veya sosyal hizmet kurumlarma, huzur evine yahut bir meslek kursuna veya eğitim kurumuna vermeye karar verebilir.

AMK m.6/2 gereğince de, aile mahkemeleri, küçiikler hakkında, onların bakımı ve gözetimi için gerekli olan parasal (nafaka) önlemleri almaya, küçüğün, bedensel veya zihinsel gelişimi için gerekli ise, ana ve babadan alarak bir sağlık veya egitim kurumuna yahut bir aile yanına yerleştirmeye veya bir iş yerine yerleştirilmesine, kuçük bir malvarlığına sahipse, bu malvarlığının korunması için gerekli önlemleri almaya karar verebilir.

Bütiin bu önlemler için, aile mahkemeleri tarafından harcama yapılması gerektiğinde, bu harcamalar, Devlet tarafından karşılanmalıdır. Ayrıca, yetişkinlerin veya küçüklerin ilgili yerlere, özellikle resmi kurum ve kuruluşların dışında, bir meslek veya sanat edinilmesini sağlamak amacıyla özel bir işyerine yerleştirilebilmeleri açısından çeşitli sorunlarla karşılaşılabilir. O nedenle, bu nitelikte, yetişkin veya küçükleri kabul etmeye hazır müessese, işletme veya işyerlerini önceden belirlemekte fayda vardır. Aksi takdirde, özel bir işletmeyi veya meslek sahibini, rızası hilâfına sorunlu bir yetişkin veya küçükle ilgilenmek zorunda burakmak ve onu HUMK m. 113/A da öngörülen hapis cezası ile tehdit etmek doğtu olmadığı gibi, istenilen sonucu vermeyeceği de açıtır.

Aile mahkemesince karar verilebilen bu önlemleri, geçici hukuki himaye tedbirlerinden, ihtiyati tedbir olarak kabul etmek mümkündür. Nitekim AMK $m$. 6 son fikra da, ihtiyati tedbir kararlarma aykır davranılması halinde öngörülen yaptırımı düzenleyen HUMK m. 113/A ya atıf yapılması da, bunu açıkça göstermektedir ${ }^{24}$.

Aile mahkemesince karara bağlanan bu önlemlerin takip ve yerine getirilmesinde AMK m.5' e göre atanan psikolog, pedagog veya sosyal çalışmacılardan biri veya birkaçı görevlendirilebilir. Ayrıca, bu uzmanların, aile mahkemesince verilen nihai kararların yerine getirilmesi esnasnda, özellikle İcra ve İflâs Kanunu m. 25'e göre çocuğun teslimine ilişkin ve m. 25a'ya göre çocukla şahsi münasebet kurulmasına ilişkin ilâmların icrasıı esnasında da hazır bulunmaları ve ilâmın icrasına yardımcı olmaları uygun olur.

Aile mahkemesince verilen koruma önlemlerine ilişkin kayarlara uyulmamásı halinde, bu karara uymayanlar, gereğini yerine getirmeyenler hakkında, HUMK'nun 113/A maddesi uygulanır ve o kimsenin eyłemi Türk

${ }^{24} \mathrm{Bu}$ konuda ayruca bkz, aşa. F.II başiı̆̆ 
Ceza Kanunu'na göre daha ağır bir cezayı gerektirmediği takdirde, bir aydan altı aya kadar hapisle cezalandırılır.

\section{3 - AMK m. 9 Gereğince Aile Mahkemesine Verilen Dava ve İşler}

"Değiştirilen ve yürürlükten kaldırılan hükümler" başlığını taşıyan AMK m. $9 / 1$ 'e göre :

"1 - 14.1.1998 tarihli ve 4320 sayılı Ailenin Korunmasına Dair Kanunun $I$ inci maddesinin birinci frkrasındaki "Sulh Hâkimi" ibaresi "Aile Mahkemesi Hâkimi" olarak değiştírilmiştir."

Böylece, söz konusu Ailenin Korunmasına Dair Kanun'un 1 inci maddesinde belirtilen önlemlere karar verme yetkisi, sulh hukuk mahkemesinden alınarak, aile mahkemesinin görev alanına dahil edilmiş olmaktadir ${ }^{25}$.

AMK m.9/2'ye göre:

“2- 18.6.1927 tarihli ve 1086 sayılı Hukuk Usulï Muhakemeleri Kanununun 8 inci maddesinin (II) numaralı bendinin (4) numaralı alt bendi aşağıdaki şekilde değiştirilmiş, (5) numaralı alt bendi yürürlükten kaldırılmış ve mevcut (6) numaralı alt bendi (5) numaralı alt bent olarak teselsül ettirilmiştir.

4. Borçlar Kanununun 91, 92 nci maddelerinde mahkeme veya hâkime verilen işleri,"

HUMK'nun 8 inci maddesinin (II) numaralı bendinin (4) numaralı alt bendi, yaptlan bu değişiklikten önce şu şekilde idi: "Türk Medeni Kanununun 198 inci maddesinde yazılı tedbirleri ve bunların değiştirilmesi veya kaldırılması isteklerini, aynı Kanunun 132, 192, 205, 327, 345 inci maddeleri ile Borçlar Kanununun 91, 92 inci maddelerinde mahkemeye veya hâkime verilen işleri,". Bu hüküm AMK m.9/2 ile "Borçlar Kanununun 91, 92 nci maddelerinde mahkeme veya hâkime verilen işleri," şeklinde degsiştirilerek, TMK'nun 198 inci maddesinde belirtilen tedbirler ile 132 , $192,205,327,345$ inci maddelerinde belirtilen dava ve işler, sulh hukuk

\footnotetext{
"Silentn Korunmasına Dair Kanun'un uygulanması açısından bkz. Balo, Yusuf: Ailenin Korunmasına Dair Kanun ve Uygulanması , (íz. BD. $2002 / 4$ ), s. 24 vd; (ayrıca Adalet Dergisi, 2002/12, s. 23 vd.); Ankara Barosu Kadın Hukuku Komisyonu : Aile İçi Şiddet ve 4320 Sayılı Ailenin Korunmasına Dair Kanun (Antalya BD. 1999/34), s.52 vd.; Yılmaz, Ejder: Geçici Hukuki Himaye Tedbirleri, Ankara 2001, s.759-762.
} 
mahkemesinin görev alanından çıkarılmış olmaktadır. Bu hükümler, zaten. TMK nun aile bukukuna ilişkin ikinci kitabında bulunmakta ve buradaki hükümlerden doğan biitün dava ve işer de aile mahkemelerine verilmiş durumdadr. Böylece, söz konusu hükümlerde düzenlenen dava ve işler de, bu şekilde sulh hukuk mahkemesinin görev alanından çıkarılıp, aile mahkemelerine aktarılmış olmaktadır.

HUMK m.8,1l/5 "evlenmeye (TMK m. 124,127) ve evlât edinmeye (TMK m. $305 v$ d) izin verilmesi isteklerini," sulh hukuk mahkemesinin görev alanına vermişti. Bu hüküm de, AMK m. $9 / 2$ ile yürürlükten kaldırılmışır. Böylece, yukarıda belirtildiği şekilde, bu izin istekleri de, sulh hukuk mahkemesinin görev alanından çıkarılıp, aile mahkemelerinin görevine dahil edilmiş̧ir.

Aile mahkemelerinin görev alanına ilişkin bu düzenlemeleri dikkate alarak, belirtmek gerekir ki, görüldügü gibi, pek çok dava ve iş, sulh hukuk mahkemesinin görev alanından çıkarılıp, aile mahkemelerine verilmiştir. Ayrı bir aile mahkemesinin bulunduğu yerlerde, bu durum , maku] görülebilirse de, ayrı bir aile mahkemesinin kurulmadı $\breve{g}_{1}$ yerlerde, aile mahkemesinin bakacağ dava ve işlere, yine oradaki asliye hukuk mahkemesi bakmak zorunda olduğundan, asliye hukuk mahkemelerinin görev alanı biraz daha genişletilirken, sulh hukuk mahkemelerinin görev alanı da oldukça daraltılmış olmaktadır. Oysa asliye hukuk malıkemelerinin görev alanı zaten oldukça geniş ve iş yükleri de fazladır. Yapılan bu düzenleme ile asliye mahkemelerinin iş yükii azaltılacağı yerde, artırılmış olmaktadır.

Ayrıca, AMK'nun 1,II inci maddesinde. "bu Kanun, aile hukukundan doğan dava ve işleri görmek üzere kurulan aile mahkemelerine dair hükümleri kapsar" denilerek, aile malkkemelerinin bakması gereken dava ve işlerin özellikle ailevi ilişkilerden kaynaklanan dava ve işler olduğu vurgulanmıştır. Oysa, Söz konusu Kanun'un $4 / 1$ inci maddesinde, aile malkkemesinin görev alanına giren dava ve işler açısından, TMK'nun ikinci kitabına bütün olarak atıf yapılımış, böylece orada düzenlenen her türlü dava ve işin aile mahkemesinde görülmesine neden olunmuştur. Bu bă̆lamda örneğin, nişanın bozulması nedeniyle açılan maddi (TMK m. 120) veya manevi (TMK m. 121) tazminat davalarl veya hediyelerin geri verilmesi (TMK m. 122), vesayet nedeniyle açılan sorumluluk davaları (TMK m. 467 vd.) vb. davaları saymak mümkündür. Oysa, bu gibi davaların, özellikle aile mahkemesinde görïlmesi gerekli değildir. Bu davalara bakacak mahkemeyi genel hükümlere (HUMK 1 vd.) göre belirlemek uygun olurdu.

Bundan başka, TMK'nun ikinci kitabının vesayete ilişkin üçüncï kısmının da (TMK m. 396 - 494), olduğu gibi, aile mahkemelerinin görev 
alanına aktarılması uygun olmamıştır. Bu durum, yukarıda belirttiğimiz gibi, sulh hukuk mahkemelerinin görev alanının daralmasına, asliye hukuk mahkemelerinin görev alanının ise, daha da genişlemesine neden olduğu gibi, vesayet makamı ve denetim makamı ilişkisinin de biraz daha karışmasına ve işlerin zorlaşıp, yavaşlamasına neden olabilir ${ }^{26}$. Bu açıdan. vesayete ilişkin TMK m. 396 - 494 hükümleri, kural olarak aile mahkemelerinin görev alanı dışında bırakılıp; bunlardan, ancak zorunlu görülenler, aile mahkemelerinin görev alanına dahil edilebilirdi.

$$
\text { II - Yetki }
$$

Aile mahkemelerinin yetkisi konusunda, AMK'da herhangi bir özel dïzenleme getirilmemiştir. Bu durumda, aile mahkemelerinin yetkisi, öncelikle, aile mahkemelerinin görev alanına giren dava ve işlere ilişkin özel yetki kuralları varsa, bu yetki kurallarına göre belirlenecektir. Bu şekilde yetkiye ilişkin özel hüküm bulunmayan hallerde de, HUMK'nun yetkiye ilişkin hükümleri genel olarak uygulama alanı bulacaktır. Nitekim, AMK m. 7,III gereğince, "özel kanunlardaki hükümler saklı kalmak kaydıyla, bu Kanunda hüküm bulunmayan konularda Türk Medeni Kanununun aile hukukuna ilişkin usul hükümleri ile Hukuk Usulü Muhakemeleri Kanunu hükümleri uygulanır," Bu hüküm gereğince de, yetkiye ilişkin özel hüküm bulunmayan hallerde, HUMK hükümleri uygulama alanı bulacaktır.

Buna göre, aile mahkemesinin görev alanına giren dava ve işlere ilişkin, Türk Medeni Kanun 'un, "aile hukuku" başhığını taşıyan ikinci kitabındaki yetkiye ilişkin hükümler, burada düzenlenen dava ve işler için öncelikle uygulama alanı bulacaktır. Bu açıdan TMK'nun ikinci kitabına baktığımızda, yetkiye iliş̧in oldukça fazla hüküm bulunduğunu görüyoruz. Bu hükümler şunlardır:

TMK m. 131, IIl'de evliliğin feshi için, davacının yerleşim yeri mahkemesi yetkili kılınmıştır; m. 160'da evlenmenin butlanı davasında yetkili mahkeme için boşanmaya ilişkin hükümlere atıf yapılmıştır: $m$. 168 'de boşanma ve ayrılık davaları için, eşlerden birinin yerleşim yeri veya davadan önce son defa altı aydan beri birlikte oturdukları yer mahkemesi yetkili kılınmıştır (karş. HUMK m. 9,III); m.177'de boşanmadan sonra açılacak nafaka davalarında, nafaka alacaklısının yerleşim yeri mahkemesi yetkili kılınmıştır; m.201'de evlilik birliğinin korunmasına yönelik önlemler (karş AMK m. 6) konusunda, eşlerden herhangi birinin yerleşim yeri mahkemesi yetkili kılınmışı̆ (ayrıca bkz. m. 201,II); m. 207 'de eşlerden birinin istemi üzerine mevcut mal rejiminin, mal ayrılığı rejimine

\footnotetext{
th AMK m. 7,Jl gereğince, vesayet makamı ve denetim makamtnın hangi mahkemeler olacağı aşă̆ıda ayrıca incelenecektir, bkz. aşa. F.Ill başlığı.
} 
dönüştürülmesi için yetkili măhkeme olarak, yine eşlerden herhangi birinin yerleşim yeri mahkemesi öngörülmüştür; m. 210'a göre, mal ortakłığm kabul etmiş eşlerden birine karşı haciz isteyen alacaklı, mal ortaklığı rejiminden zarara uğrarsa, mahkemeden mal ayrılığına karar verilmesini isteyebilir, bunun için borçlu eşin yerleşim yeri mahkemesi yetkilidir: $m$. 214'de mal rejiminin tasfiyesi için duruma göre, ölenin son yerleşim yeri, boşanma veya evliliğin iptaline ilişkin dava söz konusuysa, bu davalara bakan mahkemeler, diğer hallerde, davalı eşin yerleşim yeri mahkemesi yetkilidir: m. 265, II ye göre, mirasın kabulï veya reddi konusunda, diğer eşin rızası açısından, malhkemeye başvurulması gerekiyorsa, istem salhibi eş. kendi yerleşim yeri mahkemesine başvurabilir; m.283 gereğince, soy bağına ilişkin davalar, taraflardan birinin dava veya doğum strasındaki yerleşim yeri mahkemesinde açılır; m.312 l'e göre, küçüüün evlât edinilmesinde, ana babanın rızası eksik olursa, küçüğüun oturduğu yer mahkemesi bu rızanın aranıp aranmamasına karar verir; $m .315$ 'e göre, evlât edinme kararı, evlât edinenin oturma yeri; birlikte evlât edinmede eşlerden birinin oturma yeri mahkemesince verilir; m.326'ya göre, çocukla kişisel ilişki kurulmasıyla ilgili bütün düzenlemelerde çocuğun oturduğu yer mahkemesi de yetkilidir; m. 365,VI'ya göre, nafaka davası için yetkili mahkeme, taraflardan birinin yerleşim yeri mahkemesidir; m.41 l'e göre, vesayet işlerinde yetki küçüğüiı veya kisitlının yerleşim yerindeki vesayet dairelerine (aile mahkemesine) aittir; $m .430$ a göre, temsil kayyımı, kendisine kayyım atanacak kimsenin yerleşim yeri vesayet makamı tarafından atanır; m. 433'e göre, koruma amaciyla bir kuruma yerleştirme veya alıkoymaya karar verme yetkisi, ilgilinin yerleşim yeri veya gecikmesinde sakınca bulunan hallerde bulunduğu yer vesayet makamma aittir; son olarak m.469'a göre, Devletin vesayet dairelerinde görevli kişilere karşı rücu davasma bakmaya, vesayet dairelerinin bulunduğ yere en yakın asliye mahkemesi yetkili kılınmıştır.

TMK'nun ikinci kitabında dïzenlenen dava ve işlere ilişkin olarak, yukarıda belirtilen özel yetki kurallarının dışnda, hakkında herhangi bir yetki kuralı bulunmayan dava ve işler için veya öngörülse dahi, kesin yctki kuralının söz konusu olmadığı hallerde, HUMK'nun yetkiye jlişkin genel hükmü m.,9,I uygulama alanı bulur ve bu durumda, davalın nerleşim yeri mahkemesi (de) yetkili olur.

Aile mahkemesinin görev alanma giren davalar için belirttiğimiz, yetki kuralları, aile mahkemesinin görev alanına giren ihtiyati tedbir veya koruma önlemleri için de geçerlidir.

Aile mahkemesinin görev alanına giren bazı davalarda yetki kamu düzenine ilişkindir. Örneğin, boşanma davalarmda yetkinin kamu düzenine 
ilişkin olduğu kabul edilmektedir ${ }^{27}$. Bu gibi hallerde, örneğin boşanma davasına bakan aile mahkemesinin yetkisi konusunda açık (HUMK m.22 veya zımni (HUMK m.23) yetki sözleşmesi yapılamaz ${ }^{28}$. Ancak, Yargıtay, boşanma davalarında yetkinin kamu düzenine ilişkin olmadığı, bu nedenle, davalı ilk itiraz olarak yetki itirazında bulunmamış ise, mahkemenin kendiliğinden yetkisiz olduğunu belirterek yetkisizlik kararı veremeyeceğini belirtmektedir ${ }^{29}$. Buna bağlı olarak yetkisiz mahkemenin, yetki itirazında bulunulmaması halinde yetkili hale geleceği, dolayısıyla, tarafların bu konuda zımni yetki sözleşmesi (HUMK m. 23) yapabilecekleri de, Yargıtay'ca kabul edilmiş olmaktadır.

\section{E - DAVA AÇILMASI VE UYGULANACAK YARGILAMA USULÜ}

I - Genel Olarak

Aile mahkemeleri, yukarıda da belirttiğimiz gibi, aile hukukundan doğan uyuşmazlıklar için kurulmuş bir ilk derece mahkemesidir. Aile mahkemelerindeki yargılama usulü hakkında AMK m. 7'de özel bir düzenleme yapılmışsa da, hangi yargılama usulünün uygulanacağı açıkça belirtilmemiştir, bununla birlikte, söz konusu maddenin üçüncü fıkrasında "özel kanunlardaki hükümler saklı kalmak kaydıyla, bu Kanunda hüküm bulunmayan konularda Türk Medeni Kanununun aile hukukuna ilişkin usul hükümleri ile Hukuk Usulü Muhakemeleri Kanunu hükümleri uygulanır" denilmiştir. Buna bağlı olarak aile mahkemelerinde hangi yargılama usulünün uygulanacağı konusunda TMK'nun aile hukukuna ilişkin ikinci kitabında da bir açıklık yoktur. O nedenle, aile mahkemelerinde uygulanacak yargılama usulünü HUMK'na göre tespit etmek gerekecektir.

Bilindiği gibi, asliye hukuk mahkemelerinde kural olarak yazılı yargılama usulü (HUMK m. 178 vd) uygulanır ${ }^{30}$. AMK $\mathrm{m}$. 2'de belirtildiği üzere, aile mahkemeleri asliye hukuk mahkemesi derecesinde olmak üzere kurulduğundan, aile mahkemelerinde de, o nedenle kural olarak yazılı yargılama usulünün uygulanması gereklidir. Belirtmek gerekir ki, TMK'nun aile hukukuna ilişkin ikinci kitabında belirli dava ve işler için yargılama esnasında ne şekilde hareket edileceğine ilişkin özel usul hükümleri

${ }^{77}$ Kuru - HMU I s. 552 .

" Kuru - HMU I s.557-558.

*) Bkz. ömeğin 2.HD 30.1 1 1992, I 1 197/12088, (IKID 1993/391,s.9665-9666); HGK 22.4.1998, 2/276-297 (YKD 1999/7, s.897-900); Pekcanıtez/Atalay/Özekes s. 103.

31) Üstíndag, Saim : Medeni Yargılama Hukuku , C.I,II, 7.B.,Istanbul 2000; s.447; Kuru /Arslan/ Yilmaz s. 344. 
öngörülmüştür. Bu özel hükümler saklı kalmak üzere, aile mahkemelerinde HUMK m. 178 vol. düzenlenen yazılı yargılama usulü uygulanacaktır.

Yazılı yargılama usulü, HUMK'nda en ayrmtılı şekilde düzenlenen asıl yargılama usulüdür. Yazılı yargılama usulü, diğer yargilama usulleri. özellikle basit veya sözlü yargılama usullerine nazaran daha uzun süren ve formalitesi daha fazla olan bir yargılama usulüdür. Oysa aile mahkemelerinde, daha basit ve daha kısa bir yargılama usulünün uygulanması daha doğru olurdu. Aile hukukundan doğan uyuşmazlıklar için, özel bir aile malıkemesi kurulması kadar, belki ondan daha fazla, o mahkemelerde uygulanacak yargllama usulü de önemlidir. Zira, aile mahkemeleri kurulurken takip edilen amaç, aile hukukundan doğan uyuşmazlıkları bir şekilde çözmek değil, ailenin ve çocuğun hassasiyetine ve önemine uygun bir şekilde, daha kısa ve daha basit bir şekilde çözmek olmalıdır. Bu ise, ayrı mahkeme kurmak kadar, o mahkemede uygulanacak yargılama usulüniı de bağlıdır. Bu açıdan, AMK'da, bu malıkemelere özgü. ayrı bir yargılama usulünün öngörülmemiş olması, hele yazılı yargılama usulünün aynen kabul edilmesi büyük bir eksikliktir.

Japon hukukunda, aile mahkemesine başvurumun yazılı veya sözlü olabileceği, yargılama usulü açısından diğer hukuk mahkemelerinden farklı olarak, duruşmalarm kapalı ve gayriresmî olması kabul edilmişıı. ${ }^{31}$. Alman hukukunda da, evliliğge ilişkin davalarda yargılamanın aleni olmaması esası benimsenmiştir ${ }^{32}$. Hukukumuz açısından ise, diğer mahkemelerde olduğu gibi, aile mahkemelerinde de duruşmalar kural olarak alenidir.

Mevcut yargılama usullerinden, yazılı yargilama usulü dışında, ömeğin, basit yargılama usulii (HUMK m. 507 - 511), aile mahkemeleri için öngörülebilirdi. Gerçi uygulamada, yine uygulamadan kaynaklanan nedenlerle, yazzlı yargılama usulü ile aralarında bir farklılık kalmamasina, aynı şekilde uygulanmasına rağmen, kural olarak bu (basit yargılama) usül, yazılı yargılama usulüne nazaran daha basit ve çabuk işleyen bir yargslama usulüdür ${ }^{3:}$. Ayrıca, basit yargılama usulünde, davalı ilk oturuma kadar davalya cevap verebilir, davayı genişletme ve değiştirme yasặ̆ daha geç başlamaktadır. En önemli avantaj ise, aile mahkemeleri, görev alanına giren nafaka (HUMK m. 176/3), velayet ve vesayet işleri (HUMK m. 176/4) hariç. şu anki hali ile adli tatile tâbidir. Oysa basit yarglama usulüne tâbi dava ve işler adli tatilde de görülebildiğinden (HUMK m. 176/11), basit yarg̣lama usulii uygulansa idi, aile mahkemeleri adli tatile de tâbi olmazdı. Aile

\footnotetext{
${ }^{31}$ Sirımen / Koçhisarlıoğlu / Tanrıver / Süral / Tercan s. 14.

"Tercans. 34.

9ekcanıtez/Atalay/Özckes s. 547-548; Kuru/Arslan/Yılmaz s. 887.
} 
mahkemelerinin, faaliyet süresi yönünden adli tatil hükümlerine tabi kılınmaması uygun olurdu ${ }^{34}$.

\section{II - Dava Açılması}

Aile mahkemelerine başvuru ve dava açılması, yazılı yargılama usulü uygulandığından, dilekçe ile olur ${ }^{35}$. Dava dilekçesi, davalı sayısından bir fazla nüsha olarak hazırlanır ve mahkemeye verilir. Dava dilekçesi HUMK m. 179'daki hususlar dikkate alınarak hazırlanır; davalıya tebliğ edilir, davalı kural olarak on gün içinde cevapların yazılı olarak bildirir.

Gerek davacı, gerekse davalı, aile mahkemelerinde her türlü davalarını (dava ehliyetine sahip olmak kaydıyla) bizzat kendileri takip edebilirler, diğer mahkemelerde olduğu gibi, aile mahkemelerinde de avukat tutma zorunluluğu yoktur. Buna karşıllı, Almanya'da örneğin aile mahkemelerinde görülen evliliğe ilişkin davalarda, avukatla temsil zorunluluğu vardır (Alman Medeni Usul Kanunu (ZPO) § 78). Avukata bu davalar için özel yetki verilmesi gereklidir. Ancak avukatın özel yetkisi mahkeme tarafından araştırılmamaktadır ${ }^{36}$.

Aile mahkemelerinde, eşler, çocuklar ve ilgililer dışında, evliliğin butlanı gibi bazı hallerde, Cumhuriyet savcısı da davacı olabilir.

Aile mahkemeleri, re'sen bir aile hukuku uyuşmazlığına el atıp çözümleyemez, ancak, bir tarafın dava açması üzerine davaya bakabilir.

\section{III - Yargılama Usulï}

Yukarıda belirtildiği gibi, aile mahkemelerinde kural olarak yazılı yargılama usulü (HUMK m. 178 vd.) uygulanır. Yazılı yargılama usulünün ayrıntılarına konumuz dışında kaldığından girilmeyecektir.

Aile mahkemelerinde, kural olarak yazılı yargilama usulii uygulanmakla birlikte, TMK'nun aile hukukuna ilişkin ikinci kitabında, belirli dava ve işler için yargılama usulüne ilişkin özel hükümler de bulunmaktadır. Buna göre, aile mahkemesi, bakmakta olduğu dava veya iş için, yargılama usulüne ilişkin olarak öngörülmüş özel hüküm varsa, öncelikle bu hükümleri uygulayacaktır. Özel hükmün kapsamı dışında kalan işler için veya hakkında yargılama usulüne ilişkin özel hüküm bulunmayan dava veya işler için ise, yazılı yargılama usulünü uygulayacaktır.

\footnotetext{
${ }^{44}$ Simen / Koçhisarloğlu / Tannver / Süral / Tercan s. 30.

${ }^{35}$ Ùstündağ s. 447.

3o Jaurnig, Othmar: Zivilprozessrecht, 24. Aufl. München 1993, s. 322; Tercan s. 33.
} 
TMK'nun aile hukukuna ilişkin ikinci kitabında, belirli dava ve işler için yargıllama usulüne ilişkin olarak öngörülen özel hükümlerden bazıları şunlardır:

TMK m. 160'da evlenmenin butlanı davasındaki yargılama usulü için boşanmaya ilişkin hükümlere atıf yapılmıştır. TMK m. 184'de ise, boşanma davasinda yargllama usulü düzenlenmiş̧ir. Bu hükme göre, "boşanmada yargılama, aşağıdaki kurallar saklı kalmak üzere Hukuk Usulü Muhakemeleri Kanununa tâbidir:

1. Hâkim, boşanma veya ayrılık davasının dayandığı olguların varlığına vicdanen kanaal getirmedikçe, bunları ispatlanmış sayamaz.

2. Hâkim bu olgular hakkında gerek re'sen, gerek istem izzerine taraflara yemin öneremez.

3. Taraflarm bu konudaki her türlü ikrarları hâkimi bağlamaz.

4. Hâkim, kantları serbestçe takdir eder.

5. Boşanma veya ayrılığın fer'i sonuçlarma ilişkin anlaşmalar, hâkim tarafından onaylanmadıkça geçerli olmaz.

6. Hâkim, taraflardan birinin istemi ìzerine duruşmanın gizli yapılmasına karar verebilit."

Buna göre, evlenmenin butlanı, boşanma ve ayrılık davalarındaki yargılama usulü açısından, öncelikle bu hüküm (TMK m.184) uygulanacak, bu hükmún kapsamı dışındaki hususlarda da, yazılı yargılama usulünün ilgili hükümleri uygulama alanı bulacaktır.

Alman hukukunda da, kamu yararı nedeniyle, evliliğe ilişkin davalarda taraflarm dava konusu üzerindeki tasarruf yetkisi, önemli ölçüde daraltılmıştır ${ }^{37}$. Bu konuya ilişkin ZPO \$ 617'ye göre kabulün etkisine ilişkin hükümler ( $\mathrm{ZPO} \$ 307)^{38}$, vakıalara veya belgelerin gerçekliğine ilişkin yapılmayan veya kaçmilan açıklamalara bağlanan sonuçlar, davadan feragata, karşı tarafın, tanıkların veya bilirkişinin yeminine ilişkin hükümler Nr.472.

${ }^{37}$ Arens, Pcter / Lüke, Wolfgang : Zivilprozessrecht. 5. Aufl. München 1992. s.326.

3* Evliliğe ilişkin konularda gerçekleşen kabul, ZPO § 307 ye göre ctkiye sahip değildir; ancak. mahkeme tarafından ZPO \$ 286' ya göre serbestçe değerlenditilir (Baumbach/ Lauterbach /Albers/Hartmann: Zivilprozessordnung,52. Aufl. München 1994, s.1490). 
ve mahkeme içi ikrarın etkisine ilişkin hükümler, uygulama alanı bulamaz; keza sulh, evliliğe ilişkin davaları doğrudan doruya sona erdirme ${ }^{39}$.

Yine Alman hukukunda, 1976 tarihli Evliliğe İlişkin 1 inci Reform Kanunu ile boşanma ve sonuçlarına ilişkin konuların birlikte karara bağlanması esası (Der Verbund von Scheidungs- und Folgesachen) getirilmiştir (ZPO $§ 623$ ). Bu düzenlemeyle, evlilik daha sonra ermeden, eşler boşanmadan önce, ayrılığın veya boşanmanın hangi sonuçlara neden olacağı, ne gibi etkileri olacağı, eşlerin gözü önüne serilmekte ve böylece acele (üzerinde fazla düşünmeden karar verilen) boşanmalardan kaçınılmış olmaktadır. Pratik açıdan bu düzenleme, en çok ekonomik açıdan zayıf olan eşin korunmasına hizmet etmekte ve haklarının uygun bir şekilde teminat altına alınmaksızın evliliğin sona ermesini engellemektedir ${ }^{40}$.

TMK m. 284'de soybağına ilişkin davalarda yargılama usulti düzenlenmiştir. Bu hükme göre, "soybağına ilişskin davalarda, aşağıdaki kurallar saklı kalmak kaydıyla Hukuk Usulï Muhakemeleri Kanunu uygulanır: eder.

1. Hâkim maddî olguları re'sen araştırır ve kanıtları serbestçe takdir

2. Taraflar ve üçüncü kişiler, soybağının belirlenmesinde zorunlu olan ve sağlıkları yönünden tehlike yaratmayan araştırma ve incelemelere rıza göstermekle yükümlüdürler. Davalı hâkimin öngördüğü araştırma ve incelemeye rıza göstermezse, hâkim, durum ve koşullara göre bundan beklenen sonucu, onun aleyhine doğmuş sayabilir."

Soybağına ilişkin davalarda, bu hüküm öncelikle uygulanacak, bu hükmün kapsamı dışında kalan konularda, yine yazılı yargılama usulünün ilgili hükümleri uygulanacaktır.

TMK m. 409,II'ye göre, "akıl hastalığı veya akıl zayıflığı sebebiyle kısıtlamaya ancak resmî sağlık kurulu raporu üzerine karar verilir. Hâkim, karar vermeden önce, kurul raporunu göz önünde tutarak kısıtlanması istenen kişiyi dinleyebilir."

TMK m. 436 ve 437 'de ise, koruma amaciyla özgürlügüün kısıtlanmasında uyulacak yargılama usulü belirtilmiştir. Öncelikle, TMK m. 437 'ye göre bu işlerde, basit yargılama usulü uygulanır. TMK m. 436'ya

${ }^{39}$ Tercan $\mathbf{3 . 3 4}$.

4" Rosenberg, Leo / Schwab, Karl Heinz / Gottwald, Peter : Zivilprozessrecht, 15. Aufl. München 1993, s. 1028; Tercan s. 35. 
göre ise: "Koruma amacıyla özgürlüğün kısıtlanması, aşağıdaki kurallar saklı kalmak üzere Hukuk Usului Muhakemeleri Kanununa tâbidir:

1. Karar veriliriken ilgilinin bunun sebepleri hakkında bilgilendirilmesi ve karara karşı denetim makamına itiraz edebileceğine yazılı olarak dikkatinin çekilmesi zorunludur.

2. Bir kuruma yerleştirilen kişiye, alıkonulma kararına veya kurumdan çıkarılma isteminin reddine karşı en geç on gün içinde denetim makamına itiraz edilebileceği derhâl yazılı olarak bildirilir.

3. Mahkeme kararını gerektiren her istem, gecikmeksizin yetkili hâkime ulaştırnlir.

4. Yerleştirme kararı veren vesayet makamı veya hâkim durumun özelliklerine göre bu istemin görüşülmesini erteleyebilir.

5. Akıl hastalığı, akıl zayıflığı, alkol veya uyuşturucu madde bağımlılığı, ağı tehlike arzeden bulaşıcı hastalığı olanlar hakkında, ancak resmî sağlık kurulu raporu alındıktan sonra karar verilebilir. Vesayet makamını daha önceden biliskişiye başvurmuş olması hâlinde denetim makamı bundan vazgeçebilir."

Şu halde, koruma amacıyla özgürlüğün kısıtlanması talebi incelenirken. TMK m. 436 da belirtilen hüikümler öncelikle uygulanacaktır. Bunun dışında kalan hususlarda, bu kez TMK m. 437, I'de basit yargllama usulüne atıf yapıldığından, yazılı yargılama usulü değil, basit yargılama usulünün ilgili hükümleri uygulama alanı bulacaktır.

\section{IV - Uyuşmazlıkların Sulh Yoluyla Çözümlenmeși}

Aile mahkemeleri, AMK m.7,I gereğince "önlerine gelen dava ve işlerin özelliklerine göre, esasa girmeden önce, aile içindeki karşılıklı sevgi, saygı ve hoşgörünün korunması bakımından eşlerin ve çocuklarmn karşı karşıya oldukları sorunları tespit ederek bunların sulh yoluyla çözümünï, gerektiğinde uzmanlardan da yararlanarak teşvik eder. Sulh stuğlanamadığ takdirde yargilamaya devam olunarck esas hakkında karar verilir."

Görülduği gibi, Kanun koyucu, aile mahkemelerinin, önlerine gelen uyuşmazlıkların öncelikle sulh yoluyla çözümlenmesini istemiştir ${ }^{4 k}$.

" Nitekim. Hükümet Gerekçesinde bu konuya ilişkin olarak şöyle denilmektedir: "Tasanyla kurulması öngörülen ve bünyesinde psikolog, pedagog ve sosyal çalıştmacı bulunan aile mahkemeleri. ajle hukukundan doğan dava ve işleri, taraflar arasındaki karşılıklı sayg̨ı. 
Hükümde, "...esasa girmeden önce, ... eşlerin ve çocukların karşı karşıya oldukları sorunları tespit ederek bunların sulh yoluyla çözümünü, gerektiğinde uzmanlardan da yararlanarak teşvik eder. Sulh saģlanamadığı takdirde yargilamaya devam olunarak esas hakkında karar verilir" denildiğinden, uyuşmazlığın esası hakkında tarafların sulh olması ve uyuşmazlığın o şekilde çözünılenmesi esas olarak kabul edilmiştir. Taraflar sulh olamazsa, ancak o zaman, hakim uyuşmazlığın esasına girip, yargılama yaparak bir karar verecektir.

Kanun koyucu, aile mahkemelerinde bu şekilde sulh yoluna başvurulabileceğini açıç̧a kabul etmekle birlikte; aile hukuku sahasında, tarafların tasarruf yetkisinin kisitlı olması nedeniyle, tarafların sulh imkânlarının oldukça sınırlı olduğu kabul belirtilmekte ve şöyle denilmektedir: "Herşeyden önce evlenmenin akdi mahkeme önünde yapılacak sulh ile sağlanamaz. Bu, evlendirme dairesinin mutlak yetkisine giren bir iştir. Aynı şekilde evliliģin muteber olup olmadı̆̆ı, butlanı, feshi veya sona erdirilmesi ile ayrılık ve boşanma konularında da sulh yapılamaz. Bunlara ancak mahkeme karar verebilir. Evliliğin varlığı ve devamı gibi sorunlar da sulha konu teşkil edemezler. Buna karşlık boşanmanın veya ayrılığın fer "i hükümlerine dair taraflar arasında sulh yapılabilir",42.

Şu halde, aile mahkemesinde görülen davaların büyük bir kısmı, kamu düzeniyle yakından ilişkili olduğundan, örneğin evliğin iptali, boşanma, ayrılık davası vb. bu gibi davalar uzerinde taraflar dava konusu üzerinde serbestçe tasarrufta bulunamayacaklarından, sulh olarak davayı sona erdiremezler ${ }^{43}$ veya hakim tarafların yapmış oldukları bu sulh ile bağlı değildir; yargılamaya devam ederek bir karar verir ve dava, bu kararla sona erer (TMK m. 184). Bu durumda, AMK m. 7'de belirtilen sulhiin anlamı ve önemi ne olacaktır?

Kanaatimce, taraflar, uyuşmazlığın belirli bir yönde karara bağlanması konusunda kendileri veya hakimin girişimiyle bir anlaşmaya varmışlarsa, hakim, bu varılan anlaşmayla bağlı olmaksızın, uyuşmazlık konusu vakıaların gerçekleştiği konusunda ikna olduktan sonra, vicdani kanaatine göre yine davayı kendi verecegi bir kararla sona erdirecektir; ancak bu kararı verirken, tarafların yapmış oldukları sulhü de dikkate alacaktır. Buna göre, tarafların yapmış oldukları sulh, hakimi bağlayıp, davayı sona erdirici bir etkiye sahip olmayıp; hakimin, uyuşmazlığın esası hakkında vereceği

sevgi ve hoşgörünün korunması ilkesini gözeterek, gerektiğinde uzmanlardan da yarar[anarak. eşlerin ve çocukların karşı karşıya oldukları sorunların sulh yoluyla çözümünü sağlamaya çalışacaktır."

"2 Önen, Ergun: Medeni Yargılama Hukukunda Sulh, Ankara 1972, s. 45-46.

${ }^{43}$ Pekcanıtez / Atalay / Özekes \$. 460. 
nihai karara temel teşkil edebilir, ona yön verebilir. Dava böylece daha çabuk sontçlanabileceği gibi, temelinde kendi anlaşmaları olan bir karar da, tarafları daha çok memnun edecektir. İşte AMK m. 7'de düzenlenen sulh, tarafların üzerinde serbestçe tasarrufta bulunamayacakları davalarda, bu şekilde bir etki ve öneme sahip olabilir.

Boşanma veya ayrılığın fer'i sonuçlarına ilişkin olarak taraflarm anlaşabileceği TMK m. $184 / 5$ 'de açıł ça kabul edilmiş, ancak, bu anlaşmaların hakim tarafından onaylanarak geçerli hale geleceği belirtilmiştir. Önen”e göre “... boşanmanm veya ayrılı̆̆ın fer "i hükümlerine dair taraflar arasında sulh yapılabilir. Bu tali sonuçlar mali karakterde (tazminat, mal rejimleri, nafaka) olabileceği gibi, kişisel karakterli veya başka bir nev'iden de olabilirler. MK. Bu gibi anlaşmaların hakimin onayı olmadıkça geçerli olmayacağını öngörmekteyse de, fikrimizce bu hüküm ancak mahkeme dışı anlaşmalar için bir değer ifade eder. Bunlar mahkeme önünde yapılacak olurlarsa, ayrıca mahkemenin onayına lüzum olmasa gerektir. Zira bu anlaşmalar mahkemeler önünde yapılan sulh hükümlerine tâbi olur ve öyle muamele görürler" 4 .

AMK m. 7'de belirtildiği şekilde tarafların sulh olabilmesi için hakin. önce taraflar arasındaki uyuşmazlık hakkında, tarafların durumu hakkında, uzmanlardan da (AMK m.5) yararlanarak, ayrıntılı bilgi sahibi olmalı, uyuşmazlığın sulh yoluyla çözümlenebilmesi için gerekli ortamı ve şartları önceden hazırlamalı: gerekirse, taraflara sulhün sağlanması açıından, somut tekliflerde bulunmalıdır. Aksi takdirde, hakim, sulhün sağlanması için özverili, iyi niyetli ve sonuç alma amacıyla faaliyette bulunmazsa, bu sulh girişimi bir sonuç vermeyecektir.

AMK m. 7,I'in ifadesine göre, hakim, sulh girişimini uyuşmazlığın esasııa girmeden önce yapacak, bu mümkün olmazsa, uyuşmazlığın esasına girip karar verecektir. Burada, "sulh davanın başında sağlanamadı, bir dahal sağlanamaz" gibi bir düşïnce hissediliyor. Oysa, hakim, davanın başından sonuna, nihai karar verilene kadar, tarafları sulhe teşvik etmeli, uyuşmazlığın sulh yoluyla çözümlenmesi için çalışmalarını sürdüsmelidir.

AMK m.7.I'de hakim, uyuşmazhığın sulh yoluyla çözümlenmesini, "gerektiğinde uzmanlardan da yararlanarak teşvik eder" denilmiştir. Bu şekilde emredici bir ifade kullanıldığından, hakimin sulh girişimi, ihtiyarî olmayıp, zorunlu hale getirilmiştir. Bu hüküm, aile mabkemelerinde uygulanan yazılı yargılama usulü açısından bir yenilik getirmektedir. Zira, HUMK'nun yazılı yargılama usulüne ilişkin hükümlerinden, tahkikata yönelik m.213,l'in son kısmında hakim, “... sonuç vereceği umulan hallerde

$\longleftarrow$ Önen s. 46 . 
bunları (tarafları) sulha da teşvik edebilir" denilmiştir. Bu durumda, HUMK m. 213,I'e göre, hakim tarafları sulhe teşvik edip etmeme konusunda bir takdir yetkisine sahipken; AMK m. 7,I'de "teşvik eder" şeklinde kesin bir ifade kullanılarak, sulh girişimi zorunlu hale getirilmiş olmaktadır.

Sulh girişiminin başarıya ulaşabilmesi için hakim uzmanlardan da (AMK m. 5) yararlanabilir. Uzmanlardan yararlanıp yararlanmamak hakimin takdirine bağlıdır.

Görüldü̆ğü gibi, aile mahkemesinin sulh girişimi ancak, uyuşmazlık, özellikle eşler arasındaki uyuşmazlık, boşanma (veya ayrılık) davası şeklinde hakimin önüne geldiğinde söz konusu olabilmektedir. Aile mahkemesinin daha önce, yani uyuşmazlık kendisine yansımadan önce, bu şekilde uyuşmazlığa el koyup, sulh girişiminde bulunması ve onu çözümlemesi, mümkün değildir. Oysa, taraflar arasındaki uyuşmazlık, dava şeklinde mahkemeye yanstdıktan sonra, bu durum, taraflar arasındaki husumetin biraz daha artmasına neden olacağından, uyuşmazlığın sulh yoluyla çözümlenmesi ihtimali oldukça zayıflamaktadır. O nedenle, olması gereken açısından, sulh girişiminin daha önce gerçekleşmesi isabetli olabilirdi. Bunun için, mutlaka dava şeklinde, aile mahkemesine başvurmaya gerek kalmadan, oluşturulacak bir sulh komisyonu (uzlaştırma kurulu) bu iş için görevlendirilebilir. ${ }^{45}$. Böyle bir komisyon, yine örneğin aile mahkemesi bünyesinde oluşturulabileceği gibi, aile mahkemesi dışında kurulsa dahi, aile mahkemesi hakiminin başkanlığında da toplanabilir.

Amerika Birleşik Devletleri'ndeki bir çok eyalette aile uyuşmazlıklarının mahkemelere gitmeden çözümlenebilmesi için çeşitli yöntemler geliştirilmiştir. Arabuluculuk ve uzlaştırma, uygulanan başlıca yöntemlerdir. Japonya'da da, uzlaştırma faaliyeti, bir hakim ve genellikle biri kadın olan iki ailevi sorunları uzlaştırma komiserinden oluşan uzlaştırma komitesi tarafindan yürüttülmektedir ${ }^{46}$.

\section{F - AILE MAHKEMESINCE VERİLEBİLEN KARARLAR VE BU KARARLARA KARŞI BAŞVURULABILEN KANUN YOLLARI}

Aile mahkemeleri, aile hukukundan doğan uyuşmazlıklara bakan bir ilk derece mahkemesi olarak, bakmakta olduğu dava veya işe bağlı olarak çeşitli şekillerde karar verebilir. Bunları konumuz açısından üç başlık alı ında incelemek mümkündür ${ }^{47}$ :

${ }^{45}$ Sirmen / Koçhisarlıoğlu / Tanrıver / Süral / Tercan s. 28.

* Sirmen / Koçhisarlıoğlu / Tanrıver / Süral / Tercan s.15.

${ }^{47}$ Aile mahkemeleri de, diğer mahkemeler gibi, ara kararları verebilir, bu kararlara karşı, somut duruma göre yine aynı mahkemede itirazda bulunulabilir. Bu konu, çalışmamız açısından farklı bir özellik göstermediłinden, ayn bir başltk altında incelenmemiştir. 


\section{I - Nihai Kararlar}

Aile mahkemesinin bakmakta olduğu uyuşmazlık, dava olarak önüne gelmişse, örneğin ayrılık davası, boşanma davası, babalık davası, hediyelerin iadesi davası gibi, mahkeme bunu, yukarıda belirtildiğ̣i şekilde inceleyip karara bağlayacaktır. Mahkemenin burada verdiği karar, uyuşmazlığı esastan çözümleyen, bir nihai karardır (hükümdür) ${ }^{\text {t*. }}$.

Bu kararlar, nihaj kararlar olduğundan, bunlara karşı temyiz yoluna başvurulabilir. Aile mahkemesi kararlarına karşı da temyiz süresi asliye hukuk mahkemesinde olduğu gibi, 15 gündür; bu süre, hükmün taraflara tebliğinden itibaren işlemeye başlamalıdır (HUMK n. 432). Karar. şahısvarlığına ilişkinse, kural olarak temyiz yolu açıktır: buna karşılık menkul mal veya alacağa ilişkinse, HUMK m. 427,II'de belirtilen sımırı geçmek kaydı ile temyiz edilebilit. Temyiz sonunda Yargıtay'ın verdiği onama veya bozma kararına karşı da, yine 15 gưn içinde karar düzelíme yoluna başvurulabilir (HUMK m. 440). Karar düzeltmeye başvurulabilmesi için malvarlığma ilişkin davalarda , davanın HUMK m.440,II//1'de belirtilen miktarı geçmesi gereklidir.

\section{II - Tedbir Niteligindeki Kararlar}

Aile mahkemesi, uyuşmazlığı çözmeye yönelik nihai kararlar dışında, TMK'nun aile hukukuna ilişkin ikinci kitabında öngörülen tedbirlere ${ }^{49}$. AMK m. 6 'da öngörülen, yetişkinler veya küçükler hakkında koruyucu, eğitici ve sosyal önlemlere karar verebilir. Yine bu kapsanda olmak üzere, Ailenin Korunmasına Dair Kanun'un 1 inci maddesinde öngörüilen tedbirlere de karar verebilir ${ }^{51 !}$. Aile mahkemesi, özel olarak belirtilen bu tedbirler dışında, HUMK m. 101 vd. gereğince, ihtiyati tedbire veya İcra ve l̇flâs Kanunu m. 257 vd. gereğince, ihtiyati hacze de karar verebilir.

Mahkemenin, belirtilen konulara ilişkin olarak verdiğ kararlar, nibai kararlar olmayıp, geçici hukuki himaye tedbirlerinin bir türü olasak, ihtiyati tedbir (veya ihtiyati haciz) niteliğ taşıyan kararlardır ${ }^{5}$. O nedenle bu kararlara karşı kanun yolu olarak temyiz veya karar düzeltme yoluna gidilemez. Ancak, verilen karara karşı, yine kararı veren mahkemeye

*^ Şüphesiz. ortaya çıkan somut duruma göre, mahkeme usule ilişkin bir nihai karar verebilecç̆ gibi, davanın konusuz kalmas haline ilişkin bir karar da verebilir, bunlar da yine birer nihai karardır.

"Bu tedbirler hakikında bkz. Yılmaz s.67l vd.

${ }^{\text {\$t }}$ Bu tedbırler için bkz. yuk. dn. 25'de antlan kaynaklar.

51 Yılmaz s. 671 vd., 759 vd.; Ailenin Korunmasına Dair Kanun'un I inci maddesinde belirtilen ted̉birłer açısından bkz. Balo (Iz.BD) s. 27: Balo (Adalet Dergisi) 23 vd. 
itirazda bulunmak mümkündür (HUMK m. 107; İcra ve İflâs Kanunu m. $265)^{52}$. Nitekim, 4320 sayılı Kanun'da öngörülen tedbirler açısından Yargıtay da bu yönde karar vermekte ve şöyle demektedir: "Taraflar arasındaki davanın yapılan muhakemesi sonunda mahalli mahkemece verilen hüküm temyiz edilmekle, evrak okunup gereği görüşülüp düşünüldii: "Mahkemelerden verilen nihai kararlara karşı temyiz yoluna başvurulabilir." (HUMK md.427). Şu halde incelenen kararın niteliği ortaya konularak öncelikle kararın temyizinin kabil olup olmadığının çözümlenmesi gerekmektedir. - Davacı 4320 sayılı Kanun uyarınca tedbir alınmasını istemiş, mahkemece taraflar arasında mürafaa icrası ile üç ay süreli olarak bazı tedbirlerin alınmasına karar verilmiştir. - 4320 sayılı Kanun ile aileyi koruyucu tedbirlerin Sulh Hukuk Hakimi tarafından resen alınması hiukme bağlanmıştır. Bu Kanunun amacı aile içi şiddeti durdurma, özellikle kadını ve çocukları koruma olduğu sevk gerekçesinde açıklanmıştır. - Görüldüğg̈i üzere bu karar kusurlu eşin saldırlarına son verilmesinin kendisine ihtarından ibaret kısa süreli bir tedbir niteliğindedir. Bu açıklamalar kararın nihai nitelikte olmadı̈̆ını sürekli sonuç doğurmayacağını göstermektedir. Şu halde 4320 sayılı Kanun uyarınca oluşturulan kararları, Hukuk Usulü Muhakemeleri Kanununun 105,106,107 ve 108 inci maddelerinde belirlenen prosedür uyarınca ittihaz olunan ve bu Kanunun 109 uncu maddesi uyarınca 10 gün içinde dava açılması şartıyla değil hakimin tayin ettiği süre ile geçerli ve temyiz incelenmesine tabi bulunmayan geçici tedbir niteliğinde kabul etmek, Kanununun tedvin amacına uygun düşecektir. Temyiz isteğinin bu sebeplerle reddi gerekmiştir" ${ }^{53}$.

\section{III - Vesayet Makamı Olarak Verdiği Kararlar}

TMK m. 397,II'ye göre, vesayet makamı, sulh hukuk mahkemesi; denetim makamı ise asliye hukuk mahkemesi olarak öngörülmüştür.

Bilindigi gibi, aile mahkemeleri kurulmadan önce, vesayet makamı olarak, sulh hukuk mahkemesinin verdiği bazı kararlar, doğrudan doğruya temyiz edilemiyordu, bunlara karşı denetim makamı olarak, asliye hukuk mahkemesinde on gün içinde itiraz edilebiliyordu (örneğin TMK 461,II; 488) ${ }^{54}$.

Bu düzenlemeler, AMK (m. 1; 7,II) ile değiştirilmiş ve vesayet makamı olarak da, aile mahkemeleri kabul edilmiştir. Buna bağlı olarak ortaya çıkan denetim makamının neresi olacağı sorunu da AMK m. 7,II'de şu şekilde

${ }^{52}$ Balo (iz.BD) s. 27; Balo (AD) s.26.

${ }^{33}$ 2.HD 14.10.1998,9230/10797 (Yılmaz s. 760-761); aynı yönde 2.HD 27.1.1999, 612/228 (YIlmaz s. 761-762).

${ }^{54}$ Karu-HMU, I, s.54. 
çözümlenmiştir: "Bu Kanunun uygulanmasında, vesayet makanı olarak aile mahkemesince verilen kararlara karş1, Türk Medeni Kanununun 397 inci maddesinde belirtilen denetim makamı görevi, varsa bir sonraki numaralı aile mahkemesince, yoksa o yerdeki asliye hukuk mahkemesince, asliye mahkemesi derecesinde başka mahkeme yoksa en yakın yerdeki aile mahkemesi veya 2 inci maddenin ikinci fıkrasına göre görevlendirilen Asliye Hukuk Mahkemesince yerine getirilir."

Aile mahkemelerinin kurulmasından sonra, vesayet makamı görevi, bu mahkemelere verildiğinden, vesayet makamı olarak bunların verơiği kararlara karşı da. Kanunda belirtilen hallerde (örneğin TMK m. 461, II: 488), tıpki sulh hukuk mahkemelerinde olduğu gibi, doğrudan temyiz yoluna gidilememeli, denetim makamına, on gün içinde itiraz yoluna gidilmelidir. Denetim makamının, itiraz üzerine verdiği karara karşı da. normal temyiz yoluna başvurulmalıdır.

AMK m. 7,II'deki, hangi mahkemenin vesayet makamı ve hangisinin denetim makamı olarak görev yapacağını belirleyen kuralın çok açık olduğunu söylemek zordur. O nedenle bu kurala ilişkin olarak, söz konusu olabilecek şu ihtimallere de, hükmün açıklığa kavuşması açısından değinmek gerekmektedir:

1 - Bir yerde, birden fazla aile mahkemesi bulunuyorsa, hangisinin vesayet makamı olacağı bunlar arasındaki iş bölümü jlişkisine bağlıdır. Denetim makamı da, vesayet makamına bağlı olarak tespit edilecektir: denetim makamı, vesayet makamından bir sonraki numaralı aile mahkemesidjr. Örneğin, vesayet makamı 2 inci aile mahkemesi ise, denetim makamı 3 üncü aile mahkemesidir. Bir yerde iki tane aile mahkemesi bulunuyorsa, bunlardan birinin vesayet makamı, diğerinin denetim makamı olacağı doğaklır. Bir yerde iiç tane aile mahkemesi bulunuyorsa ve vesayet makamı da 3 üncü aile mahkemesi ise, denetim makamının I inci aile mahkemesi olması uygundur.

2 - Bir yerde sadece bir tane aile mahkemesi varsa; bu, vesayet makamı; orada bulunan asliye hukuk mahkemesi ise, denetim makamı olmalıdır.

3 - Bir yerde, aile mahkemesi bulunmuyorsa, ancak birden fazla asliye hukuk mahkemesi varsa, bu takdirde. AMK m. 2,II son cümleye göre, " aile mahkemesi kurulamayan yerlerde bu Kanunun kapsamma giren dava ve işlere, Hakinler ve Savellar Yüksek Kurulunca belirlenen Asliye Hukuk Mahkemesince bakılır." O nedenle, birden fazla asliye hukuk mahkemesinden bir tanesi , Hakimler ve Savcllar Yüksek Kurulunca aile hukukundan doğan uyuşmazlıkları çözmek için belirleneceğinden, bu mahkeme vesayet makamı olarak görev yapacaktır, aile mahkemeleri 
hakkındaki kurala (AMK m. 7,II) kıyasen, orada bulunan sonraki numaralı asliye hukuk mahkemesi de, denetim makamı olarak görev yapmalıdır.

4 - Bir yerde sadece bir tane asliye hukuk mahkemesi bulunuyorsa; bu mahkeme, vesayet makamı, oraya en yakın yerdeki aile mahkemesi veya AMK m.2,II'ye göre Hakimler ve Savcılar Yükssek Kurulunca belirlenen asliye hukuk mahkemesi de, denetim makamı olarak görev yapmalıdır.

Görüldüğü gibi, aile mahkemesi bulunmayan yerlerde de, vesayet makamı sulh hukuk mahkemesinden alınmış, asliye hukuk mahkemesine verilmiş olmaktadır ${ }^{5}$.

\footnotetext{
${ }^{55}$ Bu konuda aynca bkz. yuk. dn. 26 civarı.
} 